\title{
Complete plastid genome sequences suggest strong selection for retention of photosynthetic genes in the parasitic plant genus
}

\section{Cuscuta}

\author{
Joel R McNeal*1,2, Jennifer V Kuehl3, Jeffrey L Boore ${ }^{3,4}$ and Claude W de \\ Pamphilis $^{2}$
}

Address: ${ }^{1}$ Department of Plant Biology, University of Georgia, Athens, GA 30602, USA, ${ }^{2}$ Department of Biology, Huck Institutes of the Life Sciences, and Institute of Molecular Evolutionary Genetics, The Pennsylvania State University, University Park, Pennsylvania 16802-5301, USA, ${ }^{3}$ DOE Joint Genome Institute and Lawrence Berkeley National Laboratory, Walnut Creek, California 94598, USA and ${ }^{4}$ Genome Project Solutions, Hercules, CA 94547, USA

Email: Joel R McNeal* - jmcneal@plantbio.uga.edu; Jennifer V Kuehl - JVKuehl@lbl.gov; Jeffrey L Boore - jlboore@calmail.berkeley.edu; Claude W de Pamphilis - cwd3@psu.edu

* Corresponding author

Published: 24 October 2007

BMC Plant Biology 2007, 7:57 doi:10.1 I86/147I-2229-7-57
Received: 6 June 2007

Accepted: 24 October 2007

This article is available from: http://www.biomedcentral.com/147I-2229/7/57

(c) 2007 McNeal et al; licensee BioMed Central Ltd.

This is an Open Access article distributed under the terms of the Creative Commons Attribution License (http://creativecommons.org/licenses/by/2.0), which permits unrestricted use, distribution, and reproduction in any medium, provided the original work is properly cited.

\begin{abstract}
Background: Plastid genome content and protein sequence are highly conserved across land plants and their closest algal relatives. Parasitic plants, which obtain some or all of their nutrition through an attachment to a host plant, are often a striking exception. Heterotrophy can lead to relaxed constraint on some plastid genes or even total gene loss. We sequenced plastid genomes of two species in the parasitic genus Cuscuta along with a non-parasitic relative, Ipomoea purpurea, to investigate changes in the plastid genome that may result from transition to the parasitic lifestyle.

Results: Aside from loss of all ndh genes, Cuscuta exaltata retains photosynthetic and photorespiratory genes that evolve under strong selective constraint. Cuscuta obtusiflora has incurred substantially more change to its plastid genome, including loss of all genes for the plastidencoded RNA polymerase. Despite extensive change in gene content and greatly increased rate of overall nucleotide substitution, $C$. obtusiflora also retains all photosynthetic and photorespiratory genes with only one minor exception.

Conclusion: Although Epifagus virginiana, the only other parasitic plant with its plastid genome sequenced to date, has lost a largely overlapping set of transfer-RNA and ribosomal genes as Cuscuta, it has lost all genes related to photosynthesis and maintains a set of genes which are among the most divergent in Cuscuta. Analyses demonstrate photosynthetic genes are under the highest constraint of any genes within the plastid genomes of Cuscuta, indicating a function involving RuBisCo and electron transport through photosystems is still the primary reason for retention of the plastid genome in these species.
\end{abstract}




\section{Background}

Parasitic plants offer excellent opportunities to study changes in genome evolution that accompany the switch from an autotrophic to a heterotrophic lifestyle, a transition that has occurred many times over the course of evolution. Within angiosperms, the ability to obtain nutrition through direct attachment to a host plant has evolved at least a dozen times [1] with many additional instances of plants obtaining most or all of their nutrition through specific mycotrophic fungal interactions $[2,3]$. While approximately $90 \%$ of genes involved in photosynthesis have been transferred to the nuclear genome over the course of chloroplast evolution since divergence from free-living cyanobacterial relatives [4], these nuclear genes are often difficult to study in non-model organisms. Widespread gene and genome duplication often makes inference of orthology among nuclear genes difficult, and rate acceleration in ribosomal loci of some parasitic plants suggests that the sequences of nuclear genes may be too divergent to amplify through standard PCR [5]. By contrast, genes remaining on the plastid chromosome evolve more slowly than nuclear genes and exist as single, readily identifiable orthologs in each plastome, although the plastid chromosome itself is in high copy number per cell [6].

Many species of parasitic plants retain the ability to photosynthesize, and aside from a supplemental connection to the roots of a host, otherwise resemble fully autotrophic plants in habit [7]. Others, however, display increased dependency on their hosts, often to the extent of becoming fully heterotrophic and nonphotosynthetic. Such plants are often deemed "holoparasites", and one such species, Epifagus virginiana (Beechdrops, Orobanchaceae) is the only parasitic plant whose full plastid genome has been sequenced to date [8]. Its plastid genome is reduced to less than half the size of that in normal angiosperms due to ubiquitous gene loss, including all photosynthetic and photorespiratory genes, some ribosomal protein genes, many tRNA genes, and genes for plastid-encoded polymerase [8,9]. Despite such drastic changes, plastid transcription and intron splicing still occur $[9,10]$, presumably for the purpose of producing the four remaining proteins not related to transcription or translation. Smaller scale studies show similar or less genome reduction in related species [11-14]. For some holoparasitic lineages, existence of a functional plastid genome remains to be proven, although preliminary evidence suggests extremely divergent plastid genomes may occur in the families Balanophoraceae, Cytinaceae, Hydonoraceae, and Cynomoriaceae $[15,16]$.

A large number of studies on plastid function have been performed involving members of the parasitic genus Cuscuta, derived from within the otherwise autotrophic
Morning Glory Family (Convolvulaceae, order Solanales, class Asteridae). Plastid ultrastructure and gene content are quite variable between different taxa [17], and over 150 species exist in this widespread and recognizable genus [18]. Unlike Epifagus and other root-parasitic Orobanchaceae, Cuscuta is a twining vine with no roots at maturity. Instead, it sends its shoot like feeding organs, haustoria, directly into the stems of its hosts to invade the vasculature and obtain all necessary water and other nutrients. Leaves are reduced to vestigial scales. Despite an obligate reliance upon their hosts, many Cuscuta species show some green color, at least in their inflorescences and, particularly, in maturing ovules. Machado and Zetsche demonstrated the presence of RuBisCo, chlorophyll, and low levels of carbon fixation in Cuscuta reflexa, a member of subgenus Monogyna [19]. Additionally, although all NADH dehydrogenase $(n d h)$ genes were either undetectable or nonfunctional [20], other genes related to photosynthesis appeared to be present in functional form [21]. In this species, green plastids of normal function are localized to a ring of cells between the stem pith and cortex that are isolated from atmospheric gas exchange, indicating photosynthesis may occur in this species using recycled respiratory $\mathrm{CO}_{2}$ [22] despite an altered xanthophyll cycle in its light-harvesting complex [23].

Dot blots using poly-A selected RNA from C. reflexa as a probe also showed positive hybridization to some of the 101 tobacco genes in tobacco, although whether these results actually represent nuclear transcribed copies of the plastid genes, polyadenylated plastid transcripts, or leakage of non-polyadenylated plastid transcripts through cDNA production steps is unclear [24]. A different situation exists in Cuscuta pentagona (subgenus Grammica), which lacks the ring of photosynthetic cells observed in the stems of $C$. reflexa, but possesses what appear to be photosynthetically capable plastids with immunodetectable RuBisCo, photosystem, and light-harvesting proteins in proper locations within the plastids in green tissues of seedlings and adult plants [25]. Other species within subgenus Grammica show a range of $r b c L$ transcript levels, from low to none [17], and sampled members of this subgenus lack promoters for plastid-encoded polymerase upstream of the rrn16 and $r b c L$ genes, although transcription of $r b c L$ still occurs from nuclear-encoded polymerase promoter sites in both cases [26]. Conflicting evidence exists for Cuscuta europaea (subgenus Cuscuta), which has been described as lacking chlorophyll and detectable $r b c L$ protein [19], yet still possesses green color and more typical plastid sequences, including $r b c L$, than members of subgenus Grammica [27]. Other minor changes have been detected in the plastid genome of Cuscuta sandwichiana, such as deletion of introns within $y c f 3$, constriction of the inverted repeat to exclude $r p l 2$, $r p l 23$, and trnI, loss of $t r n V$-UAC, and reduction in size of 
$y c f 2$; slight changes to the end of atpB, size reduction of the trnL intron, and deletion of the rpl2 intron are shared with other, non-parasitic Convolvulaceae, and occurred before the evolution of parasitism in Cuscuta [28].

In this study, we test if significant changes to the plastid genome have occurred prior to the evolution of parasitism, if previously published observations of plastid genome evolution in Cuscuta apply to other members of the genus, if differences in chlorophyll content and distribution between Cuscuta species parallel differences in plastid genome content, whether plastid genes retained in Cuscuta are still evolving under strong purifying selection, and whether plastid gene retention and selective constraint suggest a photosynthetic function for plastids in this parasitic genus. To do so, we sequenced the full plastid genomes of two species of Cuscuta and a close photosynthetic relative, Ipomoea purpurea (Common Morning Glory). Ipomoea is a member of the Convolvuloideae clade, which has been shown as the most likely sister group to Cuscuta in a number of studies [27,29-31]. Cuscuta exaltata, a member of subgenus Monogyna with visible chlorophyll distributed throughout the stems and inflorescences, and Cuscuta obtusiflora, a member of subgenus Grammica that usually only exhibits green pigmentation in inflorescences, fruits, starved seedlings and stressed stem tips, were chosen to represent Cuscuta. We examined overall rates of substitution and changes in selective constraint by comparing rates of synonymous and nonsynonymous substitution for all plastid genes and across functionally defined classes of genes to determine if photosynthetic genes remain the most highly conserved in the plastid genome and whether relaxation of functional constraint precedes gene losses both before and after the evolution of parasitism in this lineage. We also tested whether patterns of transfer RNA loss, changes in intergenic regions, and rates of substitution parallel those seen in the completely nonphotosynthetic Epifagus virginiana. Finally, we use the cumulative evidence of photosynthetic localization, specific gene loss, and strong functional constraint of specific genes to suggest a photosynthetic function of the plastid genome unrelated to the Calvin Cycle in Cuscuta and perhaps other parasitic plants as well.

\section{Results and Discussion}

\section{Plastid Genome Size and Inverted Repeat Structure}

The three plastid genomes presented here all have a pair of large, inverted, identical repeat sequence (IR) separated from each other by a large single copy and small single copy region (LSC and SSC) on either end, as is the case for practically all plant plastid genomes [32]. However, considerable length variation exists between these three plastid genome sequences, with the smallest genome, Cuscuta obtusiflora, barely half the size of that in Ipomoea purpurea $(85,280$ base pairs versus $162,046 \mathrm{bp})$. Cuscuta exaltata is intermediate in size at 125,373 bp (See figs. 1, 2, 3). The plastid genome of Ipomoea is slightly larger than that of Nicotiana tabacum $(155,939$ bp), largely through expansion of the IR region into the SSC region (fig. 1). While the IR of Nicotiana barely extends into $y c f 1$, the IR of Ipomoea includes the entire $y c f 1$ gene, $r p s 15, n d h H$, and a short fragment of the first exon of $n d h A$. By contrast, the LSC end of the IR is slightly constricted, not including $r p l 2$ and $r p l 23$ as it does in Nicotiana. Previous estimates of plastid genome sizes in Convolvulaceae based upon relative size of restriction fragments using Southern blots with tobacco plastid fragments as a probe showed a similar, stepwise trend in plastid genome size reduction from a non-parasite to a member of Cuscuta subgenus Monogyna to various other species [24]. In that study, a non-parasitic member Convolvulaceae very closely related to Ipomoea, Convolvulus arvensis, gave a plastid genome size estimate $24 \mathrm{kbp}$ larger than our Ipomoea purpurea sequence ( $186 \mathrm{~kb}$ vs. 162 $\mathrm{kb}$ ). The rather large discrepancy could be due to an even larger increase in the IR size in Convolvulus relative to tobacco than is seen in Ipomoea, or it could simply reflect an inability to properly detect IR boundaries using the rough restriction fragment analysis employed in that study. Cuscuta reflexa gave a plastid genome size estimate of $122 \mathrm{kbp}$ in that study, which matches up well with the $125 \mathrm{~kb}$ size we sequenced for Cuscuta exaltata, also in subgenus Monogyna. Estimates of other Cuscuta species ranged from $81 \mathrm{kbp}$ to $104 \mathrm{kbp}$, although apparent misidentification of some of the species in that study makes further phylogenetic comparison difficult [33].

\section{Plastid Gene Content}

Gene content in Ipomoea is decidedly similar to that in Nicotiana and Atropa. These three taxa, along with both Cuscuta species, lack an intact infA [34], indicating this gene loss probably occurred prior to the divergence of Solanaceae from Convolvulaceae, both in the order Solanales. This is not surprising, as infA has been lost from the plastid many times in angiosperm evolution [35]. A second gene, ycf15, is lost across Convolvulaceae taxa sequenced in this study but is present in Solanaceae and outgroups $[34,36,37]$. However, the function of this gene is not known, and the effect of its loss in Convolvulaceae is difficult to interpret. A third gene, rpl23, is clearly a pseudogene in Cusucta exaltata and is lost completely in C. obtusiflora, but it is not clear whether it is functional in Ipomoea. Although a full length open reading frame exists in Ipomoea for rpl23, it contains two frameshift mutations and an extension of the 3 ' end. The gene also does not appear to be evolving under purifying selective constraint as in Nicotiana (see fig. 4), further indicating it may be a pseudogene, although tests of expression will be necessary to confirm this. Despite being a component of the plastid translational apparatus, the expendability of this ribosomal protein gene subunit in its plastid location is 


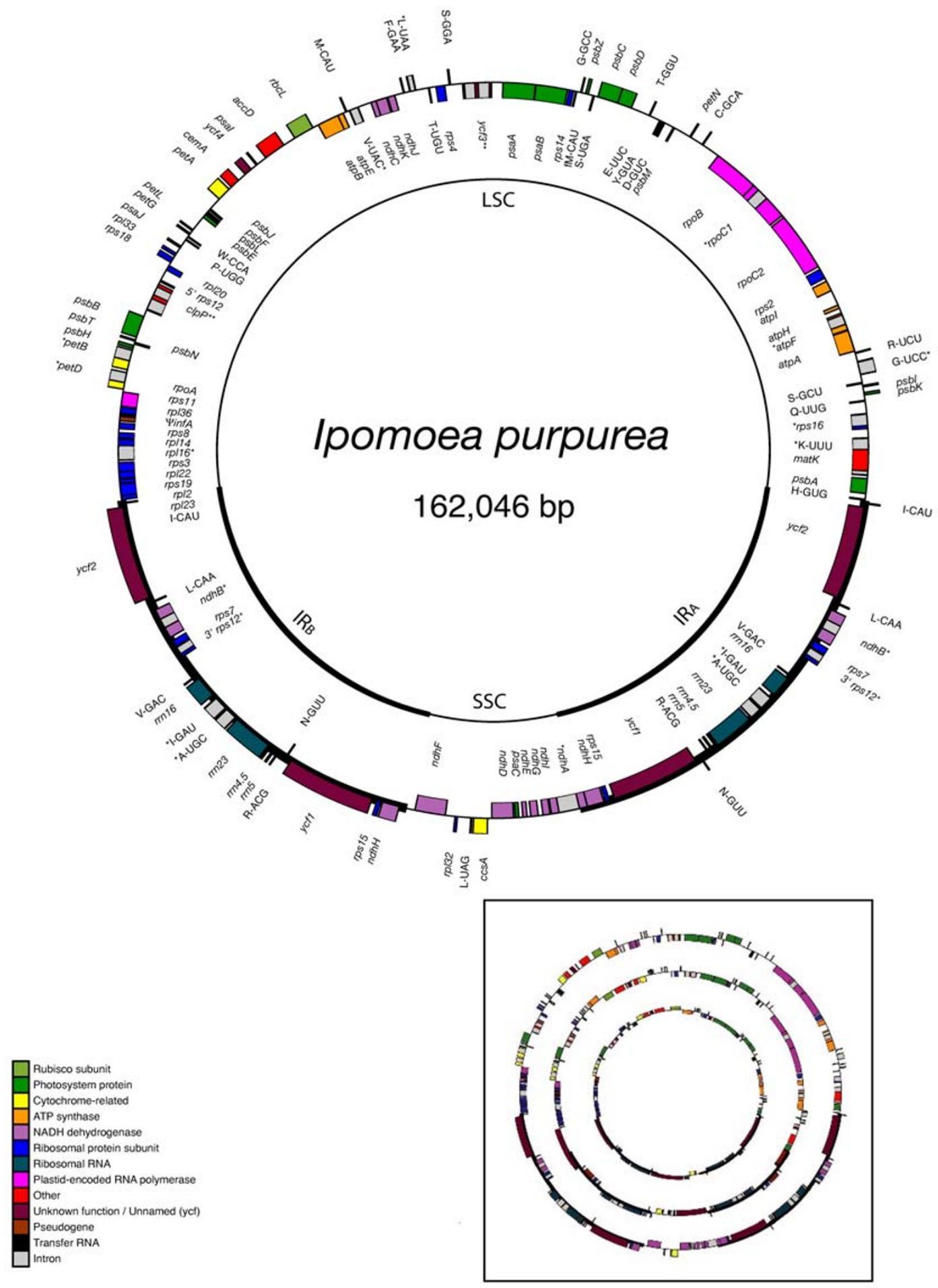

Figure 1

Circular map of the complete plastid genome of Ipomoea purpurea. The genome comprises an 88,172 bp LSC, a

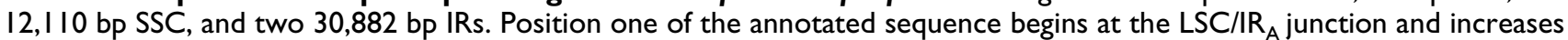
numerically counterclockwise around the genome. Genes on the inside of the circle are transcribed clockwise, those on the outside, counterclockwise. Asterisks mark genes with introns (2 asterisks mark genes with 2 introns), $\Psi$ indicates a pseudogene. INSET-Genomes scaled to relative size: Ipomoea (outermost), Cuscuta exaltata (middle), and C. obtusiflora (innermost). 


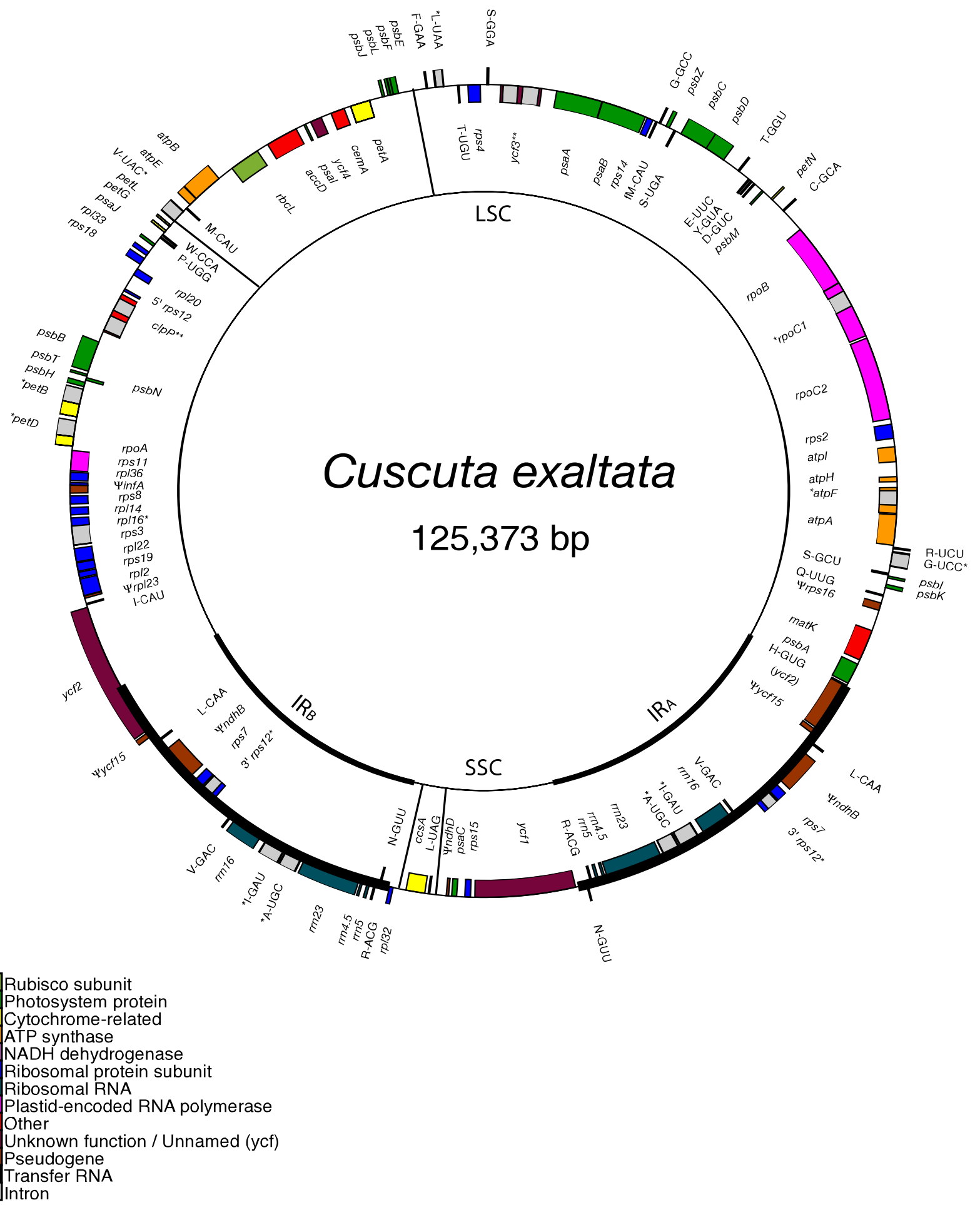

Figure 2

Circular map of the complete plastid genome of Cuscuta exaltata. The genome comprises an 82,72 I bp LSC and a 9,250 bp SSC separated by two 16,70I bp IRs. Inversion end-points are shown with lines connecting the inner circle to the outer. Position one of the annotated sequence begins at the $L S C / R_{A}$ junction and increases numerically counterclockwise around the genome. Genes are denoted as in Figure I. 


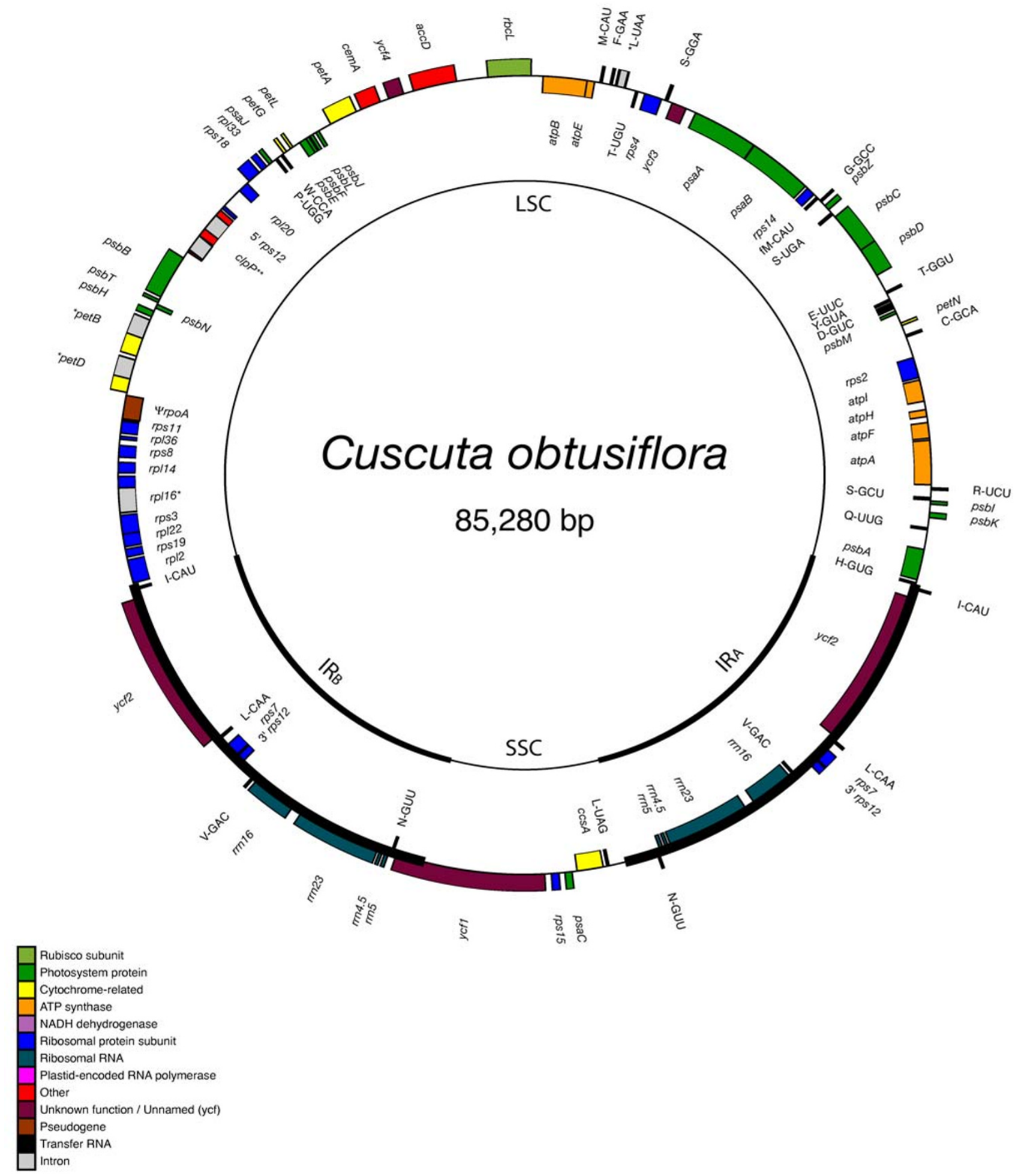

Figure 3

Circular map of the complete plastid genome of Cuscuta obtusiflora. The genome comprises a 50,20I bp LSC and a 6,817 bp SSC separated by I4,I3I bp IRs. Position one of the annotated sequence begins at the $L S C / R_{A}$ junction and increases numerically counterclockwise around the genome. Genes are denoted as in Figure I. 


\section{$d_{N} / d_{S}:$ Nicotiana and Ipomoea for all genes relative to Panax}

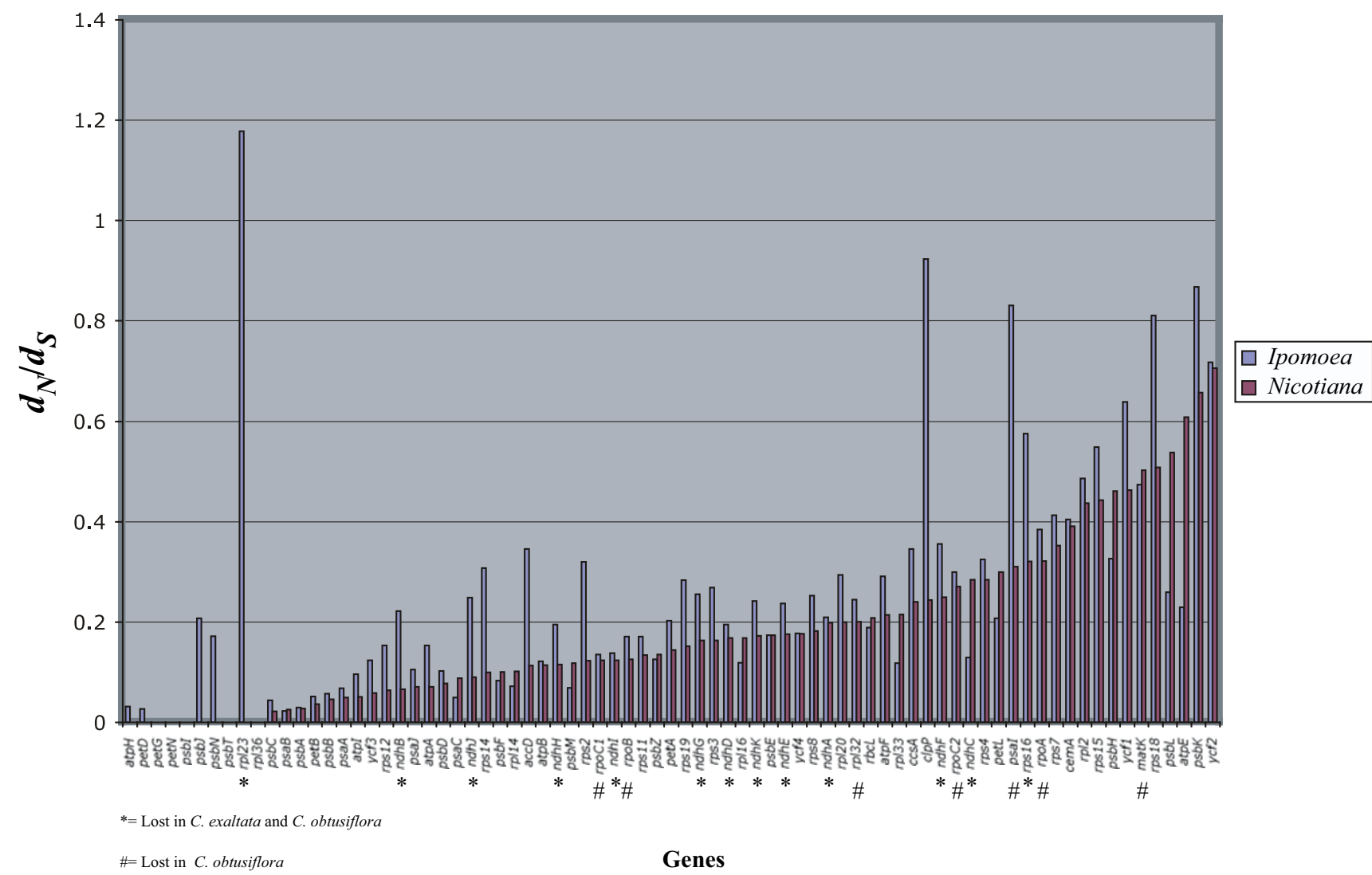

Figure 4

Pairwise $d_{N} / d_{S}$ of Nicotiana and Ipomoea vs. Panax ginseng for all shared protein-coding genes. Genes are ranked left to right by increasing $d_{N} / d_{S}$ for Nicotiana. Genes lost in Cuscuta exaltata and C. obtusiflora are indicated below the graph.

supported by its loss from the plastid genome Spinacia as well [37]. A gene found thus far only in members of Solanaceae, sprA [34], is not found in any of the sequenced Convolvulaceae genomes, indicating presence of this gene in the plastome is restricted to Solanaceae.

One gene that was surprisingly found in all three Convolvulaceae plastid genomes is $\gamma c f 1$, a large gene of unknown function previously reported as missing in Cuscuta and three other Convolvulaceae [38]. That study used Southern Blot hybridizations to screen for gene presence; $\gamma c f 1$ is still present as the second largest open reading frame in the plastid genome, but is extremely variable in size between the two Cuscuta species and is greatly elongated in Ipomoea, possesses numerous large indels, and is difficult to align with other species at the protein level in some regions These factors likely explain the negative hybridizations previously observed. Although it is one of the least conserved genes in both Cuscutas and Ipomoea, it is still apparently evolving under selective constraint as a functional gene. As is the case for $\gamma c f 15$, interpreting consequences of the extreme divergence of this gene in Convolvulaceae awaits full knowledge of its function.

Gene loss is much more prominent in the two Cuscuta species than Ipomoea. All genes lost in C. exaltata are also lost in C. obtusiflora, and are most parsimoniously assumed to be lost in the common ancestor of both species. Most notable of these losses are the $n d h$ genes, all of which are fully lost from the plastid or are pseudogenes in Cuscuta. This confirms the PCR and blot data collected for Cuscuta reflexa that suggested all $n d h$ genes were missing, highly altered, or translocated in that species [21] as well as negative PCR and sequence results from other species [28]. All $n d h$ genes are also lost from the plastid in Epifagus [9], indicatingevolution of parasitism may facilitate loss of these genes or movement to the nuclear genome. Although $n d h$ genes are retained in most photosynthetic 
plants, they are also lost from the chloroplast genome of Pinus [39], indicating their presence in the plastid genome is not necessary for photosynthesis even in fully autotrophic plants. Both Cuscuta species also lack a functional rps16 gene in the plastid, although C. exaltata contains a pseudogene with portions of both exons and the group II intron present between them. A final gene loss from both Cuscuta plastomes that is also reported in $C$. reflexa is the loss of trnK-UUU [40]. As is the case for Epifagus, C. exaltata retains the open reading frame, matK, contained within the intron of that tRNA. A deletion within the trnV -CAU intron also reported in C. reflexa [21], and similar to that seen in Orobanche minor, may hypothetically disrupt its splicing [13], but because both exons remain intact in these species, we hesitate to call it a pseudogene in C. exaltata without experimental evidence. Aside from these gene losses, plastid genome content of $C$. exaltata is identical to that in Ipomoea and includes a full set of genes presumably necessary for photosynthesis.

\section{Plastid Genome Rearrangements}

Structurally, the plastid genome of C. exaltata has undergone a number of changes relative to Ipomoea and Nicotiana. The LSC end of the IR is constricted in both Cuscuta species, but it has apparently re-extended to include a few nucleotides of trnH-GUG (4 nucleotides in C. exaltata, 6 in C. obtusiflora). As in Ipomoea, the first full gene in the LSC end of the IR in C. obtusiflora is trnI-CAU. However, the IR constriction is much more dramatic in C. exaltata, with $r p l 2$, trnI, and over half of $y c f 2$ falling outside the IR (fig. 2). Putative loss of these genes in C. reflexa detected by PCR [40] is likely an artifact of this constriction rather than a deletion, as the primers used in that study would have shown similar results for C. exaltata and not amplified the opposite LSC/IR junction at which these genes actually do exist. The IR has not extended substantially into the SSC in Cuscuta as in Ipomoea. In fact, C. exaltata is somewhat contracted relative to Nicotiana and ends slightly before the start codon of $y c f 1$. Like Nicotiana, the
IR of C. obtusiflora contains a portion of the $5^{\prime}$ end of $y c f 1$. Two segmental inversion events are observed in C. exaltata. One inversion occurs from trnV-UAC to $p s b E$ in the LSC region, the other in the SSC encompassing only two genes, $\operatorname{cs} A$ and $t r n L$-UAG. Both of these inversions border on regions that once contained $n d h$ genes. Extensive noncoding pseudogene sequence may have helped ameliorate accumulation of repeat sequences that could promote inversion. Perhaps not coincidentally, the only inversion observed in Epifagus is trnL-UAG in the SSC [8].

\section{Plastid Genome Changes in C. obtusiflora}

The plastid genome of Cuscuta obtusiflora surprisingly lacks any structural rearrangements relative to Nicotiana and Ipomoea. Unlike C. exaltata, C. obtusiflora lacks extensive pseudogene sequence and may have purged such unused DNA from its plastome before sequence motifs conducive to inversion events had time to develop. Gene loss, on the other hand, is much more rampant within $C$. obtusiflora (Table 1). In addition to the genes previously discussed for C. exaltata, C. obtusiflora has lost a third ribosomal protein gene, $r p l 32$, and five additional tRNAs. Also lost are all subunits of the plastid-encoded RNA polymerase $(r p o)$, and the intron maturase $m a t K$, the loss of which parallels loss of all group IIA introns from the genome as well, as previously reported [41]. Blot data and negative PCR results have suggested loss of plastid rpo genes from other species within subgenus Grammica as well $[26,28]$, although the $r r n$ gene cluster and $r b c L$ gene appear to still be transcribed from nuclear-encoded polymerase in at least some species [42]. Despite such extensive gene loss from the plastome, C. obtusiflora retains all plastid genes directly involved in photosynthesis within the chloroplast, including all atp genes, all pet genes, $r b c L$, and all $p s a$ and $p s b$ genes, with the exception of psaI. This gene is one of the smallest in the plastome (36 codons or less), although it is highly conserved across land plants. Losses of $\operatorname{trnV}$ and two introns within $y c f 3$ reported for another member of subgenus Grammica, Cus-

Table I: Plastid gene loss relative to Panax ginseng

\begin{tabular}{|c|c|c|c|}
\hline Gene Type & Ipomoea purpurea & Cuscuta exaltata & Cuscuta obtusiflora \\
\hline NADH dehydrogenase & & $\begin{array}{l}n d h A, \Psi \text { ndhB, ndhC, } \Psi \text { ndhD, ndhE, } \\
\text { ndhF, ndhG, ndhH, ndhl, ndhJ, ndhK }\end{array}$ & $\begin{array}{l}n d h A, n d h B, n d h C, n d h D, n d h E \\
n d h F, n d h G, n d h H, n d h l, n d h J, n d h K,\end{array}$ \\
\hline Photosystem Protein & & & psal \\
\hline Ribosomal Protein & ( $\Psi$ rp/23?) & $\Psi$ rpl23, $\Psi$ rps $/ 6$ & $r p / 23, r p / 32, r p s / 6$ \\
\hline Transfer-RNA & & trnK-UUU & $\begin{array}{l}\text { trnA-UGC,trnG-UCC, trnl- } \\
\text { GAU,trnK-UUU, trnR-ACG }+, t r n V- \\
\text { UAC }\end{array}$ \\
\hline RNA polymerase & & & $\Psi$ rpoA, rрoB, rроCl, rрoC2 \\
\hline Initiation factor & $\Psi \operatorname{infA} * \dagger$ & $\Psi$ infA*† & $\inf A^{*} \dagger$ \\
\hline Unknown & ycfl 5 & $\Psi$ ycfl 5 & ycfl 5 \\
\hline Intron maturase & & & matK† \\
\hline
\end{tabular}

* Also nonfunctional in Nicotiana tabacum and Atropa belladonna

† Still present in Epifagus virginiana 
cuta sandwichiana [28], are also present in Cuscuta obtusiflora.

\section{Selective Constraint in Plastid Genes}

With these three new full plastid genome sequences, we tested whether substantial changes in selective pressure of genes, particularly those lost in Cuscuta, occurred prior to evolution of parasitism in this lineage. After calculating corrected distances of nonsynonymous nucleotide substitution per nonsynonymous site $\left(d_{N}\right)$ and synonymous substitution per synonymous site $\left(d_{S}\right)$ for all genes in Ipomoea and Nicotiana relative to a common outgroup, Panax, an interesting trend toward relaxed selection in the genome of the fully autotrophic Ipomoea was revealed (fig. 4). Of 77 protein-coding genes shared between the two taxa, $56(72.7 \%)$ have a higher $d_{N} / d_{S}$ in Ipomoea than in Nicotiana, with only 15 genes showing higher $d_{N} / d_{S}$ in Nicotiana (6 genes were indistinguishable or had $d_{N} / d_{S}<$ 0.01 in both taxa). Furthermore, $12 / 13$ genes lost in both Cuscuta species had higher $d_{N} / d_{S}$ in Ipomoea, indicating these genes may have already been under relaxed selection prior to the evolution of parasitism in Convolvulaceae. Using likelihood methods, all previously defined classes of genes (atp, pet, $p s, r p, r p o$, and $n d h$ ) with the exception of pet showed significantly greater overall rates of substitution in Ipomoea than in Nicotiana in pairwise relative rates test using Panax as an outgroup (Table 2). Analysis of the combined set of $n d h$ genes revealed that the ratio of nonsynonymous substitution rates to synonymous substitution rates $(\mathrm{R})$ on the branch leading to Ipomoea is much higher than in the previous branch in the tree leading to Solanales leading to an extremely significant difference in the likelihood of the tree when left unconstrained
( $\mathrm{p}<0.0001$, Table 3$)$, suggesting relaxed selection in $n d h$ genes probably began before the advent of parasitism.

Pairwise relative rates tests also show significant overall rate differences between Ipomoea and Cuscuta exaltata as well as between the two Cuscuta species for all types of genes (Table 2). We next wanted to test whether ratios of overall selection between classes of genes remaining in Cuscuta are similar to autotrophic taxa. Figure 5 shows how patterns of synonymous and nonsynonymous substitution vary between sampled Solanalean taxa relative to Panax for the various classes of genes in the plastome. While there are minor changes in synonymous rates between different gene classes, relative ratio tests of synonymous rates for the tree topologies of each gene class yielded no significant differences (Table 2). However, nonsynonymous rate values for $p s$ genes were significantly different from both atp and $r p$ genes, and there were lower nonsynonymous rates and $\mathrm{R}$ for pet and ps genes in all pairwise comparisons performed (fig. $5 b$ and $5 c$ ). The trend in Cuscuta is clearly symmetrical to other taxa; all classes of genes appear to be evolving under strong negative selection with $\mathrm{R}$ much lower than 1 , and photosystem and pet genes remain the most highly conserved, even in the rapidly evolving $C$. obtusiflora genome. Despite the loss of psaI in C. obtusiflora, selective constraint on the plastid genome of both Cuscuta species strongly suggests that a photosynthetic process remains the primary purpose of their plastid genomes.

Although plastid genes in Cuscuta are still evolving under strong negative selection, the data show that they are somewhat relaxed compared to their fully autotrophic rel-

Table 2: Results of pairwise relative rates and relative ratio tests

\begin{tabular}{|c|c|c|c|}
\hline A & & & \\
\hline \multicolumn{4}{|l|}{ Pairwise Relative Rates Tests } \\
\hline Taxa compared & C. exaltata vs. C. obtusiflora & C. exaltata vs. Ipomoea & Ipomoea vs. Nicotiana \\
\hline Outgroup & Ipomoea & Nicotiana & Panax \\
\hline atp & $* * *$ & $* * *$ & $0.00377^{*}$ \\
\hline pet & $* * *$ & **** & 0.257 \\
\hline ps & $* * *$ & $* * *$ & $* * *$ \\
\hline rp & $* * *$ & $* * *$ & $* * *$ \\
\hline rpo & & $* * *$ & $* * *$ \\
\hline ndh & & & $* * *$ \\
\hline \multicolumn{4}{|l|}{ B } \\
\hline \multicolumn{4}{|l|}{ Relative Ratio Tests } \\
\hline$\underline{\text { Gene Classes Compared }}$ & atp vs. pet & atp vs. ps & atp vs. $r p$ \\
\hline$d N$ & 0.246 & $0.00634 *$ & 0.0231 \\
\hline$d S$ & 0.186 & 0.0254 & 0.116543 \\
\hline Gene Classes Compared & pet vs. ps & pet vs. $r p$ & ps vs. $r p$ \\
\hline$d N$ & 0.0783 & 0.0554 & **** \\
\hline$d S$ & 0.983 & 0.911 & 0.27 \\
\hline
\end{tabular}

$*_{p}<0.01, *^{*} \mathrm{p}<0.001$, *** $\mathrm{p}<0.000 \mathrm{I}$. All significant results remain significant after sequential Bonferroni tests as described in Rice, W.R. 1989. Evolution. 43: 223-225. 
A

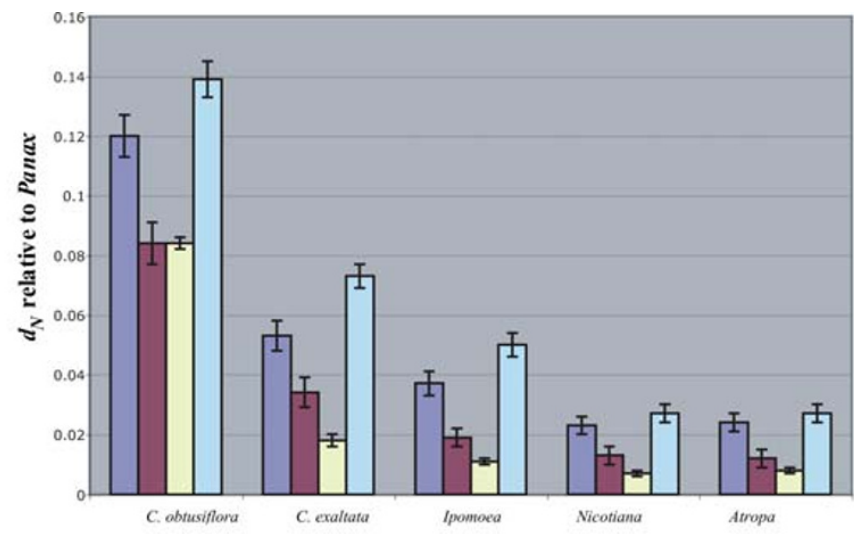

B

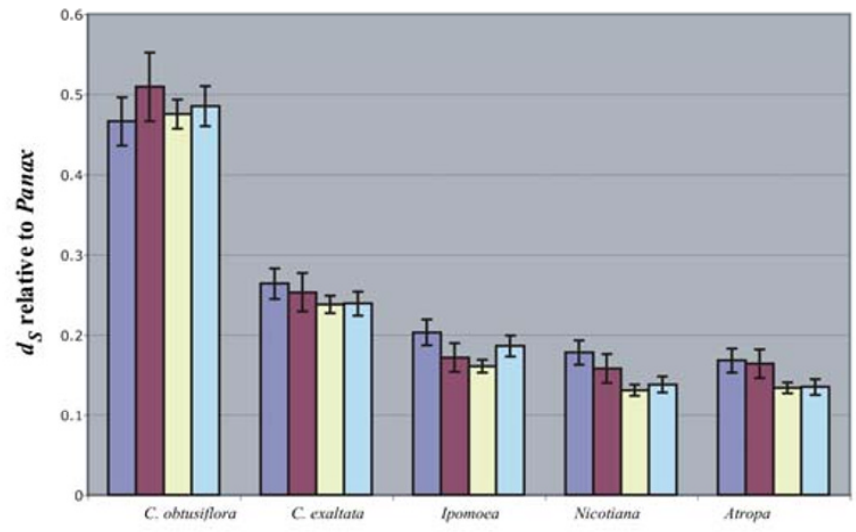

$\square$ ATP synthase (atp)

$\square$ Cytochrome C (pet)

$\square$ Photosystem (ps)

$\square$ Ribosomal Protein $(r p)$

$\mathrm{C}$

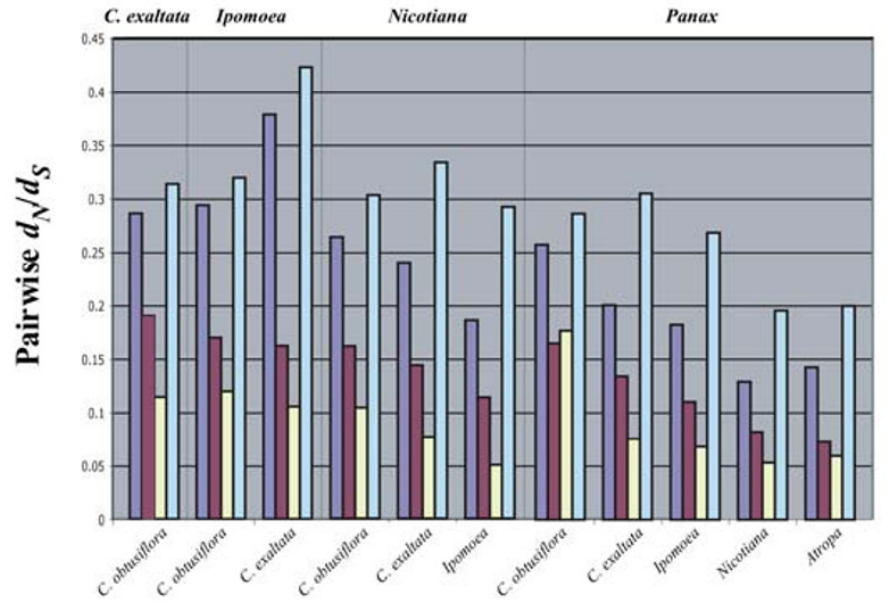

Figure 5

Rates of substitution and selection across 4 functionally-defined classes of genes. A- $d_{N}$ estimates and standard errors vs Panax for Atropa, Nicotiana, Ipomoea, $C$. exaltata, and C. obtusiflora. B- $d_{S}$ vs Panax for the same taxa. C. Pairwise $d_{N} / d_{S}$ for the same taxa vs. Panax; Ipomoea, C. exaltata, and C. obtusiflora vs. Nicotiana; C. exaltata and C. obtusiflora vs. Ipomoea, and C. exaltata vs. $C$. obtusiflora. 

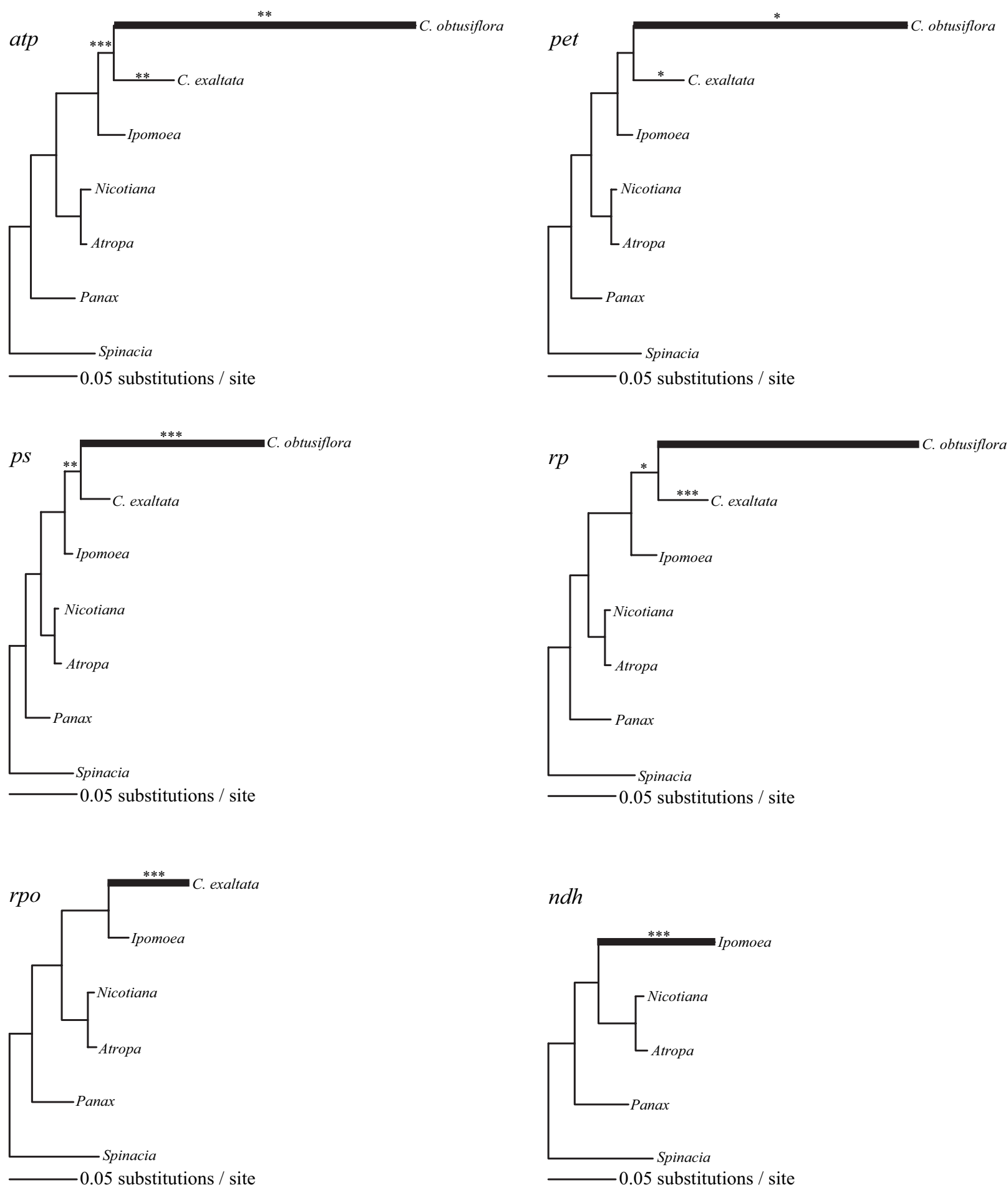

Figure 6

Phylogenetic trees created using Maximum Likelihood GTR+gamma for each functionally defined gene class. Branches with significantly higher (LRT, $p<0.0 \mathrm{I})$ rates of synonymous substitution per site are thickened. Branches with significantly higher $d_{N} / d_{S}$ are marked with one $(\mathrm{p}<0.0 \mathrm{I})$, two, $(\mathrm{p}<0.00 \mathrm{I})$, or three asterisks $(\mathrm{p}<0.000 \mathrm{I})$. Values of $d_{S}$ and $d_{N} / d_{S}$ on relevant branches are given in Table 3. 
atives. Figure 6 shows phylograms for each of the previously discussed gene classes with significant increases in synonymous rates and $\mathrm{R}$ as determined by LRTs indicated on the branches. The overall synonymous rate for C. obtusiflora varies between 5 and 8 times that of the branch leading to Convolvulaceae across the four classes of genes for which it could be studied, while that of C. exaltata is nearly identical (Table 3 ). These highly accelerated substitution rates in C. obtusiflora could be the result of shorter generation time, damage to repair machinery allowed by relaxed selective constraint, or, alternatively, could result from a lower organismal or plastid genome population size [43]. Strongly negative selective pressure in C. obtusiflora, particularly in ps and pet genes, occurring in spite of highly accelerated rates of nucleotide substitu- tion further supports the idea that C. obtusiflora must be utilizing its photosynthetic genes for some purpose important to the plant. This is particularly fascinating considering full loss of plastid-encoded polymerase. While Epifagus virginiana has been shown to perform transcription of ribosomal and various other protein coding genes in the absence of plastid rpo genes $[9,10]$, this phenomenon is unknown from any photosynthetic plant. In large part, plastid polymerase performs the transcriptional duties for photosynthetic genes in typical green plants, but a dramatic shift seems to have occurred in Cuscuta toward imported nuclear polymerase transcription of all genes. Many plastid genes are known to be transcribed by both polymerases [44], and whether or not autotrophic relatives of Cuscuta obtusiflora already possess the ability to tran-

Table 3: Rates of synonymous substitution and ratio of nonsynonymous to synonymous substitution

\begin{tabular}{|c|c|c|c|}
\hline$\underline{a t p}$ & $\underline{R_{N}} / \underline{R}_{\underline{S}}$ & $\underline{R}_{\underline{S}}$ & $\begin{array}{c}\text { Synonymous rate increase }(x \\
\text { Convolvulaceae) }\end{array}$ \\
\hline Globally constrained & 0.184 & 0.205 & \\
\hline Solanales & 0.0885 & 0.136 & \\
\hline Convolvulaceae & 0.133 & 0.189 & \\
\hline Cuscuta & $0.82 I^{* * * *}$ & 0.0206 & \\
\hline C. exaltata & $0.264^{* *}$ & 0.216 & 1.14 \\
\hline C. obtusiflora & $0.231^{* *}$ & $0.959 * * *$ & 5.07 \\
\hline \multicolumn{4}{|l|}{ pet } \\
\hline Globally constrained & 0.114 & 0.208 & \\
\hline Solanales & 0.0381 & 0.131 & \\
\hline Convolvulaceae & 0.0907 & 0.135 & \\
\hline Cuscuta & 0.0606 & 0.127 & \\
\hline C. exaltata & $0.245 *$ & 0.16 & 1.19 \\
\hline C. obtusiflora & $0.154 *$ & $1.037 * * *$ & 7.68 \\
\hline \multicolumn{4}{|l|}{$\underline{p s}$} \\
\hline Globally constrained & 0.0728 & 0.191 & \\
\hline Solanales & 0.0402 & 0.106 & \\
\hline Convolvulaceae & 0.046 & 0.159 & \\
\hline Cuscuta & $0.138^{* *}$ & 0.0847 & \\
\hline C. exaltata & 0.0859 & 0.17 & 1.07 \\
\hline C. obtusiflora & $0.103^{* * *}$ & 0.91 *** & 5.72 \\
\hline \multicolumn{4}{|l|}{$\underline{r p}$} \\
\hline Globally constrained & 0.227 & 0.184 & \\
\hline Solanales & 0.0988 & 0.106 & \\
\hline Convolvulaceae & 0.267 & 0.157 & \\
\hline Cuscuta & $0.314 *$ & 0.0959 & \\
\hline C. exaltata & $0.390 * * *$ & 0.148 & 0.94 \\
\hline C. obtusiflora & 0.232 & 0.901 *** & 5.74 \\
\hline \multicolumn{4}{|l|}{ rpo } \\
\hline Globally constrained & 0.231 & 0.175 & \\
\hline Solanales & 0.144 & 0.163 & \\
\hline Convolvulaceae & 0.218 & 0.211 & \\
\hline C. exaltata & $0.435^{* * *}$ & $0.253^{* * *}$ & 1.2 \\
\hline \multicolumn{4}{|l|}{ ndh } \\
\hline Globally constrained & 0.19 & 0.223 & \\
\hline Solanales & 0.181 & 0.114 & \\
\hline Ipomoea & $0.284^{* * *}$ & $0.401 * * *$ & \\
\hline
\end{tabular}

Significance of rate differences determined by comparing fully constrained tree likelihood to tree with specified node unconstrained. $* \mathrm{p}<0.01$, $*^{*} \mathrm{p}<0.00 \mathrm{I}$, *** $\mathrm{p}<0.000 \mathrm{I}$. All significant results remain significant after sequential Bonferroni tests as described in Rice, W.R. 1989. Evolution.43: 223-225. 
scribe all genes with imported nuclear polymerase or whether novel promoters and transcription factor binding sites evolved rather recently remains to be seen.

\section{Plastid Genome Differences in Cuscuta versus Epifagus virginiana}

Although Epifagus virginiana has undergone a similar downsizing of its plastid genome, it and Cuscuta are quite different in a number of ways, most obviously in that Cuscuta retains a seemingly functional set of photosynthetic genes while Epifagus has lost all such genes. With the loss of rpo genes in both taxa, we investigated whether both taxa show similar patterns of deletion in intergenic regions, which should contain plastid promoters, transcription-factor binding sites, and other motifs no longer necessary in a nuclear-transcribed plastome. Overall, Epifagus has 22 fewer protein coding genes and 7 fewer tRNA genes than C. obtusiflora. While the plastid genome size of Epifagus (70,028 bp) is over 15 kilobases smaller than that of C. obtusiflora, this is actually less than would be expected given such a dramatic difference in overall gene content. In 63 non-coding, intergenic regions between homologous functional genes in both Cuscuta species, Ipomoea, and Nicotiana, C. obtusiflora (11714) has undergone a $49 \%$ overall decrease in length relative to Nicotiana $(22,996 \mathrm{bp})$, perhaps largely due to a deletion of plastid polymerase and transcription factor binding sites. C. exaltata has decreased $16 \%$ over the same area, and Ipomoea only $1 \%$. Over the 16 intergenic regions shared by Epifagus, C. obtusiflora has decreased by $33 \%$ relative to Nicotiana, while Epifagus has only decreased by slightly over 3\% (values in Table 4A). Likewise, in 3 regions for which conserved functional genes flanking regions containing homologously defunct genes could be compared between Epifagus and C. obtusiflora, Epifagus exhibits a 32\% total decrease in size relative to the full length sequences containing functional genes in Nicotiana, while C. obtusiflora is $85 \%$ shorter (Table 4B). The IR of Epifagus is almost the same length as that of a normal angiosperm, while its SSC and LSC regions are the sites of practically all of its gene loss. Cuscuta obtusiflora has extensive deletion in those areas too, but also exhibits a significant contraction of the IR, largely through pseudogene loss relative to Epifagus. While Cuscuta obtusiflora almost completely lacks pseudogene sequences, Epifagus retains a fair number of them. Coupled with various intron losses, the plastid genome of C. obtusiflora is much more streamlined than that of Epifagus.

We also wanted to test whether genes remaining in the plastid of the fully nonphotosynthetic Epifagus are under less constraint than those of the putatively photosynthetic Cuscuta species. Surprisingly, among the alignable genes they share, C. obtusiflora is usually more divergent at the protein level from a common outgroup, Panax (fig. 7).
Comparison of $d_{N} / d_{S}$ across all genes shows no clear trend, with some genes under greater constraint in Epifagus than in C. obtusiflora and others more conserved in Cuscuta (fig. 8).

C. obtusiflora retains the four protein-coding genes in Epifagus not related to transcription or translation and presumably the reason for retaining a plastid genome in that species: $a c c D, c l p P, \gamma c f 1$, and $\gamma c f 2$ [8]. accD and $c l p P$ both are less constrained in Cuscuta than in Epifagus, and in $c l p P$, dramatically so, with all three Convolvulaceae taxa exhibiting higher $d_{N} / d_{S}$ for both genes. The effect this has on the amino acid divergence is also very apparent (fig. 7). $c l p P$ is a protease that is essential for shoot development in Nicotiana, but exactly which proteins it targets for degradation are still unknown [45]. Why it is so divergent in the closely related autotroph, Ipomoea, also has yet to be deduced. While alignable regions of $y c f 1$ and $y c f 2$ actually have lower $d_{N} / d_{S}$ in C. obtusiflora than for Epifagus, other regions of each gene are unalignable at even the protein level in Cuscuta while Epifagus is relatively easy to align, and overall protein divergence is actually much higher for C. obtusiflora than Epifagus in these genes. Overall, with the exception of photosynthetic genes, the plastid genome of Cuscuta obtusiflora is more streamlined, less constrained, and more divergent than Epifagus for the genes they share in common. Whether this indicates faster overall evolutionary rates in C. obtusiflora or simply a longer time as a specialized parasite under relaxed constraint is difficult to discern without accurate dating methods and more taxon sampling.

\section{Comparisons with other Nonphotosynthetic Lineages}

Despite some differences in patterns of evolution, many parallels exist between plastid genome evolution in Cuscuta and that of the related but independently derived parasitic lineage Orobanchaceae, including Epifagus. Both lineages show overall increased rates of nucleotide substitution, relaxed selective constraint, and lack any appreciable shift in synonymous codon usage in spite of loss of multiple tRNAs [46](Table 5). Substantial gene loss is observed in both lineages; in addition to sharing loss of all $n d h$ and rpo genes with C. obtusiflora, Epifagus has lost a largely overlapping set of tRNAs from its plastid genome. All tRNAs lost in C. obtusiflora are also lost in Epifagus with the exception of trnR-ACG, and even that has been suggested to be a pseudogene [13]. The three ribosomal proteins lost in C. obtusiflora are also a subset of the six lost in Epifagus. Although Epifagus lacks all photosynthetic genes, other Orobanchaceae retain genes normally required for photosynthesis in seemingly functional form. Lathraea clandestina has what appears to be a functional $r b c L$ (RuBisCo, large subunit) gene, and rpo genes are also amplifiable by PCR, despite the fact that the plant apparently lacks chlorophyll and spends its entire life 
Table 4: (A) Intergenic distance between shared, intact coding sequence and (B) Shared pseudogene sequence relative to Nicotiana

\begin{tabular}{|c|c|c|c|c|c|}
\hline$A$ & & & & & \\
\hline $\begin{array}{l}\frac{\text { Region }}{\text { (flanking }} \\
\text { genes) }\end{array}$ & Epifagus & C. obtusiffra & C. exaltata & Ipomoea & Nicotiana \\
\hline rpl20-rps $/ 2$ & 745 & 720 & 799 & 814 & 811 \\
\hline $\operatorname{trnN-ycfl}$ & 323 & 113 & 537 & 402 & 328 \\
\hline$r r n 4.5-r r n 5$ & 233 & 83 & 218 & $24 I$ & 256 \\
\hline $\operatorname{trnW}$-trnP & 225 & 153 & 74 & 169 & 164 \\
\hline rps/8-rp/20 & 213 & 102 & 244 & 257 & 205 \\
\hline $\begin{array}{l}\text { rrn23- } \\
\text { rrn4.5 }\end{array}$ & 188 & 80 & 100 & 101 & 101 \\
\hline trnS-rps 4 & 182 & 119 & 310 & 313 & 333 \\
\hline rpll 6-rps3 & 162 & 79 & 159 & 166 & 146 \\
\hline $\operatorname{trnD}$-trnY & 151 & 54 & 106 & 106 & 108 \\
\hline$r p s / 2-c l p P$ & 138 & 81 & 187 & 187 & $14 \mid$ \\
\hline $\begin{array}{l}\text { trnfM- } \\
\text { rps / } 4\end{array}$ & 133 & 126 & 152 & 144 & 152 \\
\hline rp/33-rps /8 & 115 & 124 & 185 & 193 & 189 \\
\hline rps II-rpl36 & 108 & 103 & 100 & 94 & 104 \\
\hline trnY-trnE & 80 & 68 & 70 & 55 & 59 \\
\hline rps/9-rp/2 & 62 & 96 & 64 & 51 & 63 \\
\hline rps7-rps / 2 & 47 & 48 & 53 & 53 & 53 \\
\hline $\operatorname{trn} Q-p s b K$ & & 350 & 360 & 370 & 347 \\
\hline $\operatorname{trnR}$-atpA & & 101 & 87 & 108 & 126 \\
\hline$a t p A-a t p F$ & & 66 & 61 & 59 & 54 \\
\hline atpF-atpH & & 202 & 294 & 353 & 401 \\
\hline atpH-atpl & & 289 & 744 & 1113 & 1160 \\
\hline atpl-rps2 & & 79 & 412 & 239 & 229 \\
\hline $\operatorname{trnC}$-petN & & 347 & 709 & 928 & 670 \\
\hline petN-psbM & & 353 & 497 & 1197 & 1138 \\
\hline psbM-trnD & & 94 & 459 & 660 & 1072 \\
\hline trnE-trnT & & 200 & 585 & 747 & 848 \\
\hline $\operatorname{trn} T-p s b D$ & & 636 & 868 & 1322 & 1218 \\
\hline psbC-trnS & & 107 & 283 & 250 & 242 \\
\hline trnS-psbZ & & 133 & 262 & 351 & 362 \\
\hline psbZ-trnG & & 168 & 285 & 278 & 278 \\
\hline $\operatorname{trnG-trnfM}$ & & 89 & 100 & 270 & 227 \\
\hline rps/4-psaB & & 98 & 100 & 128 & 125 \\
\hline psaB-psaA & & 19 & 28 & 28 & 28 \\
\hline psaA-yç3 & & 349 & 724 & 790 & 752 \\
\hline ycß3-trnS & & 166 & 576 & 829 & 1716 \\
\hline rps4-trnT & & 240 & 425 & 457 & 371 \\
\hline trnT-trnL & & 370 & 660 & 875 & 710 \\
\hline trnL-trnF & & 113 & 357 & 371 & 356 \\
\hline $\operatorname{trnM-atpE}$ & & 172 & 209 & 211 & 224 \\
\hline atpB-rbcL & & 401 & 799 & 414 & 817 \\
\hline rbcL-accD & & 1053 & 584 & 899 & 767 \\
\hline ycf4-cemA & & 296 & 517 & 616 & 222 \\
\hline cemA-petA & & 170 & 318 & 220 & 230 \\
\hline petA-psbJ & & 458 & 642 & 909 & $107 \mid$ \\
\hline psbJ-psbL & & 115 & 167 & 137 & 127 \\
\hline$p s b L-p s b F$ & & 40 & 25 & 25 & 25 \\
\hline petL-petG & & 171 & 257 & 230 & 184 \\
\hline petG-trnW & & 50 & 124 & $13 \mid$ & 134 \\
\hline trnP-psaj & & 125 & 392 & 543 & 438 \\
\hline psaj-rp/33 & & 114 & 356 & 460 & 434 \\
\hline$c l p P-p s b B$ & & 253 & 565 & 511 & 445 \\
\hline psbB-psbT & & 110 & 163 & 203 & 203 \\
\hline$p s b T-p s b N$ & & 60 & 62 & 71 & 82 \\
\hline$p s b N-p s b H$ & & 122 & 110 & 116 & 111 \\
\hline psbH-petB & & 120 & 130 & 133 & 129 \\
\hline
\end{tabular}


Table 4: (A) Intergenic distance between shared, intact coding sequence and (B) Shared pseudogene sequence relative to Nicotiana

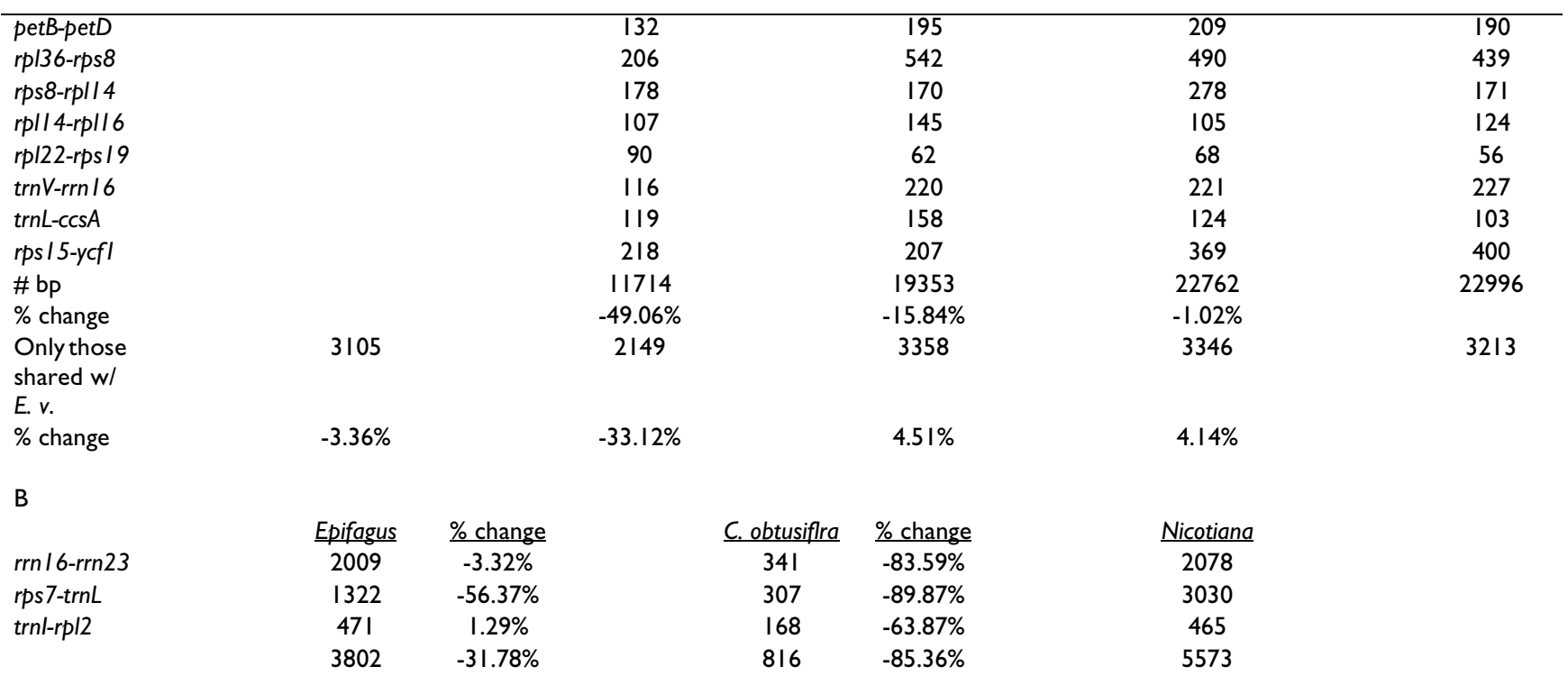

Pseudogene sequence is defined as intergenic spacer regions between conserved genes that once contained one or more genes no longer present in functional form in either species.

cycle underground except when flowering [12]. Similarly, some members of the genus Orobanche and other holoparasites within the family retain $r b c L$ genes that appear to be evolving under functional constraint [47-49]. Pholisma, a genus in the holoparasitic family Lennoaceae, is yet another example of an independently nonphotosynthetic lineage retaining $r b c L$ [50]. Without full plastid genome sequence from these plants, it is difficult to know whether they too may still possess a necessary complement of plastid genes for residual photosynthesis, although unlike the Cuscuta species in this study, they lack obvious chlorophyll at any life stage and are not above ground to encounter light for most of their life cycle.

Other non-angiosperm plastid-containing parasite lineages also show patterns of plastid gene loss and loss of selective constraint. Apicomplexan apicoplast genomes, which are thought to be derived from a plastid ancestor, are more similar to Epifagus than Cuscuta in that they contain only a few genes not involved in transcription or translation, none of which are related to photosynthesis. However, none of the remaining non-transcriptional/ translational genes are shared with Epifagus, and RNA polymerase genes are retained in apicoplast genomes [51]. The euglenoid parasite Astasia longa also has a highly reduced plastid genome but like Cuscuta retains $r b c L$ [52]. Nonphotosynthetic algae are variable in plastid genome content; the only genes not involved in transcription or translation that are normally found in angiosperms in the plastid genome of Helicosporidium are $y c f 1$ and $a c c D$, two of the four such genes retained in parallel by Epifagus [53]. Prototheca also retains ATP synthase genes, part of the photosynthetic apparatus also retained by Cuscuta but lost in
Epifagus[54]. Although some parallels exist, each independently derived parasite lineage appears to follow a unique pathway in plastid genome reduction.

\section{Lipid Biosynthesis as a Hypothesis for Photosynthetic Gene Retention in Cuscuta}

While it has been hypothesized that the plastid genome must be retained at least minimally in nonphotosynthetic organisms for the transcription of trnE, an essential product for tetrapyrrole synthesis in the plastid[55], retention of a conserved photosynthetic apparatus in Cuscuta suggests another important role for the plastid genome in these parasites. Because no atmospheric gas exchange occurs with chlorophyllous cells in C. reflexa, recycling of respiratory carbon dioxide has been presented as a hypothesis for retention of photosynthesis in that species, and although their source carbohydrates all apparently originate from the host, a net decline in carbon dioxide release is indeed detected in the presence of light [22]. However, recycling carbon dioxide back to carbohydrate through the Calvin cycle is not the only potential reason for retaining photosynthesis. Another possible explanation for conservation of photosynthetic genes in Cuscuta and retention of $r b c L$ in other holoparasities may lie in a recently described alternative function of RuBisCo involving lipid biosynthesis, where it acts independently of its formerly known role in Calvin cycle production of carbohydrates. In this alternative pathway, 20\% more acetylCoA is available for fatty acid biosynthesis, and $40 \%$ less carbon is lost as carbon dioxide in green seeds of Brassica napus. This pathway is still largely reliant on ATP and NADPH generated during the light reactions of photosynthesis, although less than $15 \%$ of that necessary for the 


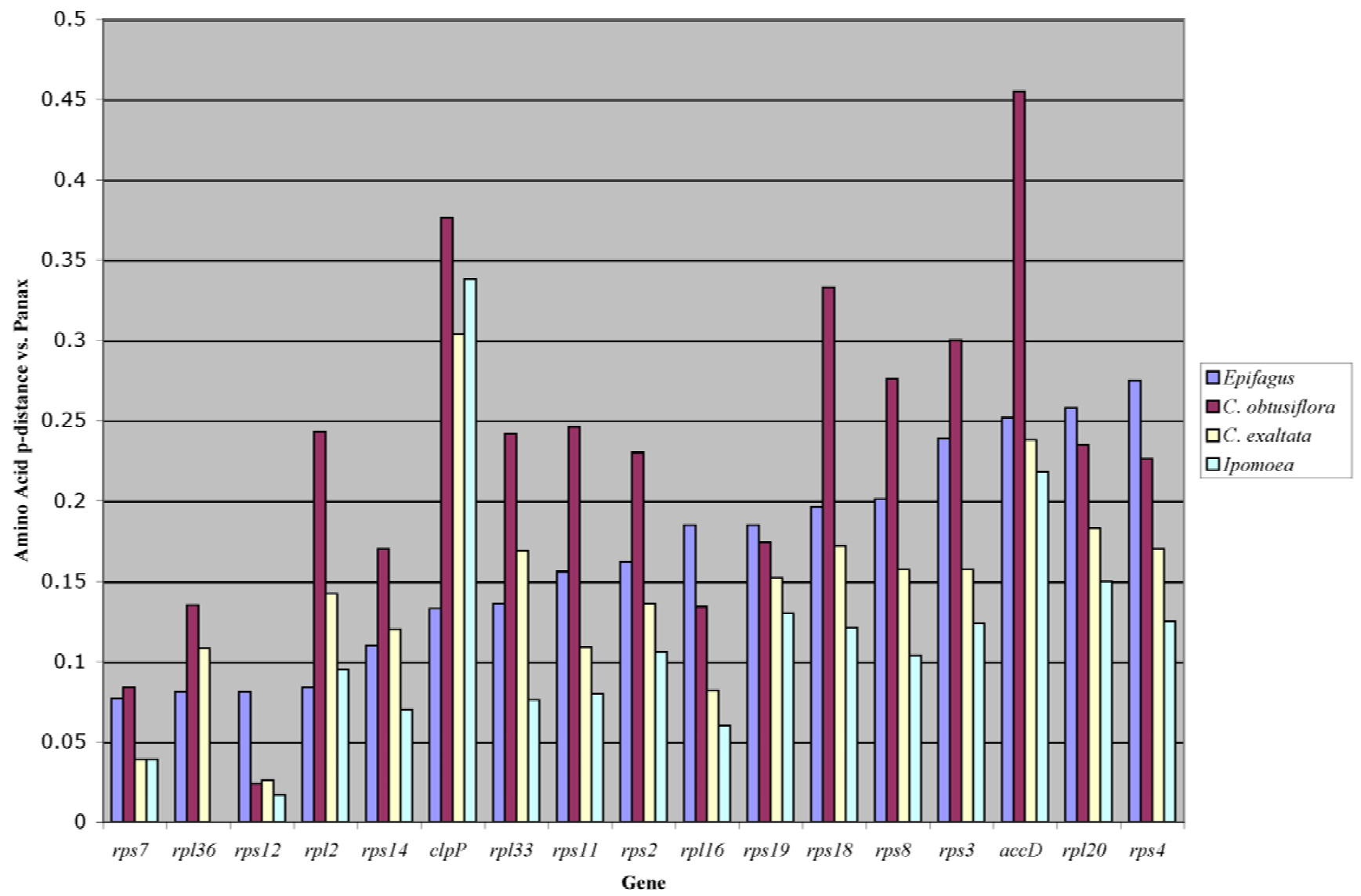

Figure 7

Amino acid p-distance for Epifagus, Ipomoea, C. exaltata, and C. obtusiflora vs.Panax across most genes present in Epifagus. Most genes are less altered relative to the outgroup in Epifagus than in Cuscuta obtusiflora, and the non-transcriptional/translational genes remaining in Epifagus (clpP and $a c c D)$ are particularly divergent in C. obtusiflora.

Calvin cycle is needed for this function of RuBisCo to play a dominant role in lipid synthesis [56]. No atmospheric carbon dioxide would be necessary for this process, and it could also explain the observation of less respiratory carbon dioxide loss during light exposure [22], when necessary ATP and NADPH for the reaction would be produced. Chlorophyll is most concentrated in developing ovules and seeds of Cuscuta obtusiflora and close relatives in subgenus Grammica like Cuscuta pentagona, which has been shown to lack the circular ring of chlorophyllous cells between the pith and cortex [57]. Because Cuscuta species must survive long enough after germination to search for and attach to a host, utilizing this alternative function of photosynthesis for efficient lipid allocation to seeds and subsequent efficient carbon use in the free-living seedlings may explain the need for an intact photosynthetic apparatus in this parasitic lineage.
Use of RuBisCo for lipid biosynthesis may also explain retention of $r b c L$ in other holoparasite angiosperm plastids and in the parasitic euglenoid Astasia. One of the few genes for which the plastid genome is transcribed in Epifagus and Helicosporidium, accD, is a subunit of acetyl co-A carboxylase, indicating that lipid biosynthesis remains an important function of plastids in these species as well. Lipid biosynthesis has already been experimentally demonstrated as a major function of apicoplasts and plastids in a number of nonphotosynthetic non-angiosperm species $[58,59]$. Future physiological study of photosynthetic tissues in Cuscuta as well as other parasitic plants, which may have largely if not entirely lost the primary photosynthetic function of their plastid genomes, should lead to greater understanding of possible alternate roles of the plastid genome in parasitic and autotrophic plants alike. 


\section{$d_{N} / d_{S}$ all genes, all taxa vs. Panax}

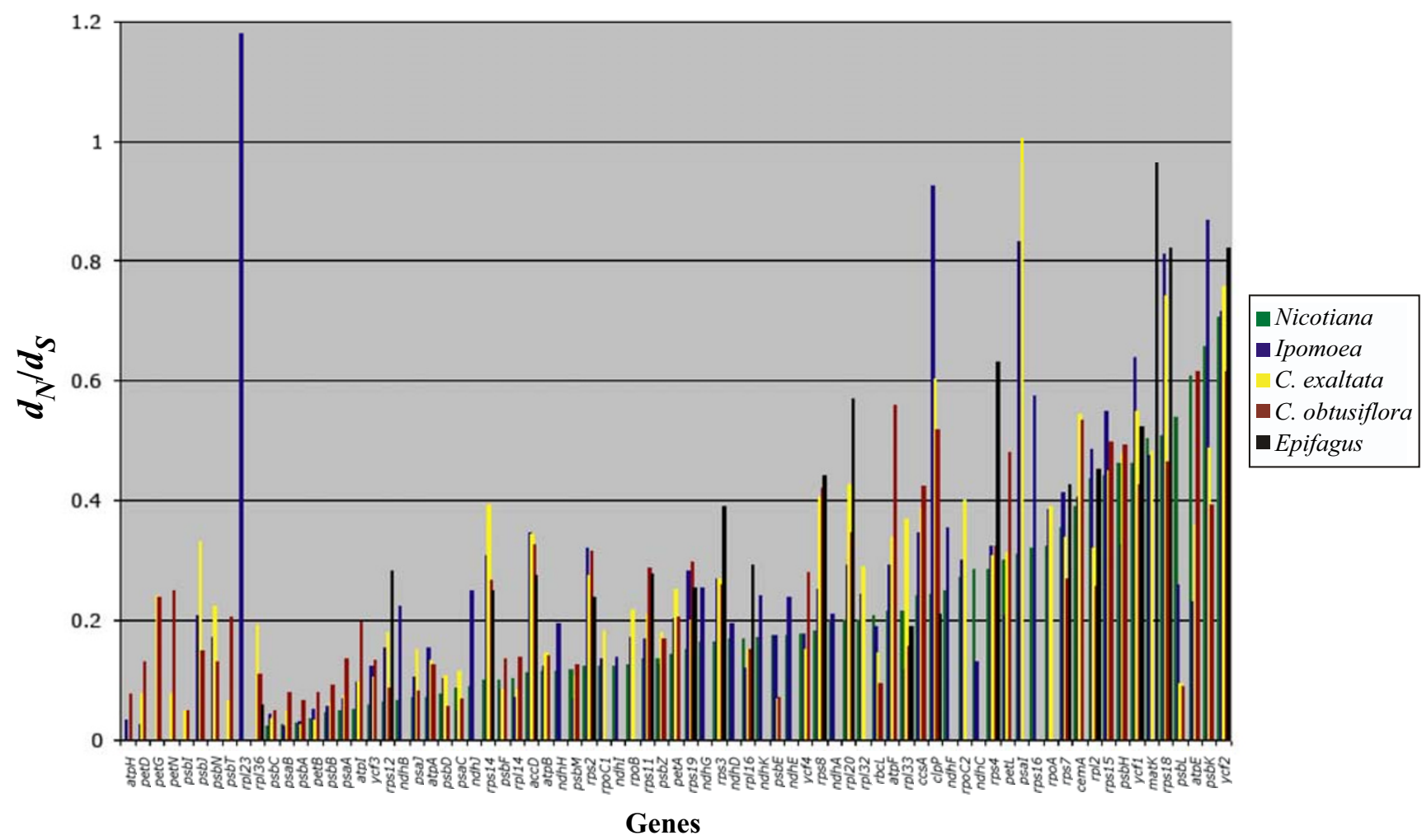

Figure 8

$\boldsymbol{d}_{\boldsymbol{N}} / \boldsymbol{d}_{\mathbf{S}}$ for all genes, all taxa (including Epifagus) vs.Panax. Most genes evolve more quickly in Ipomoea than in Nicotiana (tobacco), indicating relaxed constraint on plastid genes even before evolution of parasitism in Convolvulaceae. Constraint is further relaxed in Cuscuta exaltata and is most relaxed in Cuscuta obtusiflora, although photosynthetically related genes remain highly constrained. In general, genes present in Epifagus virginiana are under higher levels of constraint than in Cuscuta obtusiflora, despite the retention of photosynthetic genes in Cuscuta.

\section{Conclusion}

By sequencing the full plastid genomes of two parasitic angiosperms in the genus Cuscuta and a non-parasitic close relative, Ipomoea, we have been able to gain a better understanding of the directional downsizing of the plastid genome in heterotrophs as dependence on photosynthesis for carbohydrate production decreases. These genomes are greatly complemented by comparison to that already existing for the parasitic angiosperm Epifagus virginiana; by studying the similarities and the differences between these two parasitic lineages, we have unveiled a clearer picture of which changes to the plastid genome might be expected to occur in all transitions to heterotrophy, which might be peculiar to those plants lacking chlorophyll, and which may be lineage specific to Cuscuta. We find ndh genes to be the only genes functionally lost during the transition to parasitism in Cuscuta, while more extensive loss of both coding and noncoding material has occurred more recently. Despite substantial reduction of the plastid genome in Cuscuta, the most highly conserved genes continue to be those directly involved in photosynthesis, whereas those genes shared with the fully nonphotosynthetic Epifagus are amongst the least conserved. We postulate that the extremely high levels of constraint on remaining photosynthetic genes may indicate an important function for these gene products in lipid biosynthesis rather than carbohydrate production through the Calvin Cycle.

\section{Methods \\ Plastid Genome Sequencing, Assembly, and Annotation}

Seeds of all three species were germinated and grown in the Pennsylvania State University Biology Greenhouse. An heirloom cultivar of Ipomoea purpurea, "Grandpa Ott's", was used to decrease likelihood of heteroplasmy within the sample. One gram of young leaf tissue was used for 
Table 5: Relative synonymous codon usage (RSCU) patterns across the plastid genomes

\begin{tabular}{|c|c|c|c|c|c|c|c|}
\hline$\underline{\mathrm{AA}}$ & Codon & $\underline{N}$ & $\underline{\text { RSCU }}$ & $\underline{\mathrm{AA}}$ & Codon & $\underline{N}$ & $\underline{\mathrm{RSCU}}$ \\
\hline \multicolumn{8}{|c|}{ A. Ipomoea Cumulative Codon Usage } \\
\hline \multirow[t]{2}{*}{ Phe } & UUU & 907 & 1.33 & Ser & UCU & 463 & 1.53 \\
\hline & UUC & 455 & 0.67 & & UCC & 291 & 0.96 \\
\hline \multirow[t]{2}{*}{ Leu } & UUA & 742 & 1.91 & & UCA & 344 & 1.14 \\
\hline & UUG & 467 & 1.2 & & UCG & 184 & 0.61 \\
\hline \multirow[t]{2}{*}{ Tyr } & UAU & 649 & 1.6 & Cys & UGU & 211 & 1.45 \\
\hline & UAC & 160 & 0.4 & & UGC & 80 & 0.55 \\
\hline ter & UAA & & 0 & ter & UGA & & 0 \\
\hline ter & UAG & & 0 & Trp & UGG & 407 & 1 \\
\hline \multirow[t]{4}{*}{ Leu } & CUU & 523 & 1.35 & Pro & $\mathrm{CCU}$ & 347 & 1.49 \\
\hline & CUC & 149 & 0.38 & & CCC & 194 & 0.84 \\
\hline & CUA & 314 & 0.81 & & $\mathrm{CCA}$ & 257 & 1.11 \\
\hline & CUG & 135 & 0.35 & & CCG & $13 \mid$ & 0.56 \\
\hline \multirow[t]{2}{*}{$\mathrm{His}$} & CAU & 392 & 1.49 & Arg & CGU & 284 & 1.23 \\
\hline & CAC & 135 & 0.51 & & CGC & 107 & 0.46 \\
\hline \multirow[t]{2}{*}{ Gln } & CAA & 631 & 1.56 & & CGA & 315 & 1.37 \\
\hline & CAG & 180 & 0.44 & & CGG & 112 & 0.49 \\
\hline \multirow[t]{3}{*}{ Ile } & AUU & 957 & 1.5 & Thr & $\mathrm{ACU}$ & 505 & 1.61 \\
\hline & $A \cup C$ & 389 & 0.61 & & $A C C$ & 257 & 0.82 \\
\hline & AUA & 562 & 0.88 & & $\mathrm{ACA}$ & 358 & 1.14 \\
\hline Met & $A \cup G$ & 511 & 1 & & $A C G$ & 132 & 0.42 \\
\hline \multirow[t]{2}{*}{ Asn } & AAU & 828 & 1.54 & Ser & AGU & 377 & 1.25 \\
\hline & AAC & 247 & 0.46 & & AGC & 155 & 0.51 \\
\hline \multirow[t]{2}{*}{ Lys } & AAA & 938 & 1.49 & Arg & AGA & 410 & 1.78 \\
\hline & AAG & 317 & 0.51 & & AGG & 153 & 0.66 \\
\hline \multirow[t]{4}{*}{ Val } & GUU & 437 & 1.45 & Ala & GCU & 591 & 1.83 \\
\hline & GUC & 148 & 0.49 & & GCC & 197 & 0.61 \\
\hline & GUA & 448 & 1.49 & & GCA & 353 & 1.09 \\
\hline & GUG & 170 & 0.57 & & GCG & 152 & 0.47 \\
\hline \multirow[t]{2}{*}{ Asp } & GAU & 698 & 1.58 & Gly & GGU & 508 & 1.3 \\
\hline & GAC & 186 & 0.42 & & GGC & 171 & 0.44 \\
\hline \multirow[t]{2}{*}{ Glu } & GAA & 900 & 1.47 & & GGA & 579 & 1.48 \\
\hline & GAG & 326 & 0.53 & & GGG & 304 & 0.78 \\
\hline \multicolumn{8}{|c|}{ B. C. exaltata Cumulative Codon Usage } \\
\hline \multirow[t]{2}{*}{ Phe } & UUU & 769 & $1.4 \mathrm{I}$ & Ser & UCU & 355 & 1.55 \\
\hline & UUC & 321 & 0.59 & & UCC & 214 & 0.94 \\
\hline Leu & UUA & 627 & 1.9 & & UCA & 260 & 1.14 \\
\hline & UUG & 424 & 1.29 & & UCG & 149 & 0.65 \\
\hline Tyr & UAU & 517 & 1.62 & Cys & UGU & 150 & 1.46 \\
\hline & UAC & 123 & 0.38 & & UGC & 55 & 0.54 \\
\hline ter & UAA & & 0 & ter & UGA & & 0 \\
\hline ter & UAG & & 0 & Trp & UGG & 322 & 1 \\
\hline Leu & CUU & 405 & 1.23 & Pro & $\mathrm{CCU}$ & 263 & 1.33 \\
\hline & CUC & 130 & 0.39 & & $\mathrm{CCC}$ & 187 & 0.95 \\
\hline & CUA & 264 & 0.8 & & $\mathrm{CCA}$ & 201 & 1.02 \\
\hline & CUG & 128 & 0.39 & & CCG & 139 & 0.7 \\
\hline His & CAU & 350 & 1.48 & Arg & CGU & 242 & 1.22 \\
\hline & CAC & 122 & 0.52 & & CGC & 102 & 0.51 \\
\hline Gln & CAA & 530 & 1.52 & & CGA & 273 & 1.37 \\
\hline & CAG & 168 & 0.48 & & CGG & 117 & 0.59 \\
\hline Ile & AUU & 753 & 1.5 & Thr & $\mathrm{ACU}$ & 428 & 1.67 \\
\hline & AUC & 271 & 0.54 & & $A C C$ & 210 & 0.82 \\
\hline & $\mathrm{A} \cup \mathrm{A}$ & 482 & 0.96 & & $\mathrm{ACA}$ & 280 & 1.09 \\
\hline Met & AUG & 385 & I & & ACG & 105 & 0.41 \\
\hline Asn & $\mathrm{AAU}$ & 684 & 1.5 & Ser & AGU & 299 & 1.31 \\
\hline & AAC & 226 & 0.5 & & AGC & 93 & 0.41 \\
\hline Lys & AAA & 860 & 1.56 & Arg & AGA & 326 & 1.64 \\
\hline & AAG & 243 & 0.44 & & AGG & 135 & 0.68 \\
\hline Val & GUU & 372 & 1.42 & Ala & GCU & 464 & 1.73 \\
\hline
\end{tabular}


Table 5: Relative synonymous codon usage (RSCU) patterns across the plastid genomes (Continued)

\begin{tabular}{|c|c|c|c|c|c|c|c|}
\hline & GUC & 132 & 0.5 & & GCC & 186 & 0.69 \\
\hline & GUA & 378 & 1.44 & & GCA & 292 & 1.09 \\
\hline & GUG & 165 & 0.63 & & GCG & 133 & 0.49 \\
\hline \multirow[t]{2}{*}{ Asp } & GAU & 571 & 1.55 & Gly & GGU & 395 & 1.2 \\
\hline & GAC & 167 & 0.45 & & GGC & 173 & 0.53 \\
\hline \multirow[t]{2}{*}{ Glu } & GAA & 716 & 1.48 & & GGA & 462 & 1.4 \\
\hline & GAG & 254 & 0.52 & & GGG & 288 & 0.87 \\
\hline \multicolumn{8}{|c|}{ C. C. obtusiflora Cumulative Codon Usage } \\
\hline \multirow[t]{2}{*}{ Phe } & UUU & 649 & 1.51 & Ser & UCU & 262 & 1.56 \\
\hline & UUC & 213 & 0.49 & & UCC & 138 & 0.82 \\
\hline \multirow[t]{2}{*}{ Leu } & UUA & 559 & 2.14 & & UCA & 203 & 1.21 \\
\hline & UUG & 292 & 1.12 & & UCG & 108 & 0.64 \\
\hline \multirow[t]{2}{*}{ Tyr } & UAU & 392 & 1.71 & Cys & UGU & 112 & 1.53 \\
\hline & UAC & 67 & 0.29 & & UGC & 34 & 0.47 \\
\hline ter & UAA & & 0 & ter & UGA & & 0 \\
\hline ter & UAG & & 0 & Trp & UGG & 264 & I \\
\hline \multirow[t]{4}{*}{ Leu } & CUU & 323 & 1.24 & Pro & $\mathrm{CCU}$ & 207 & 1.41 \\
\hline & CUC & 88 & 0.34 & & $\mathrm{CCC}$ & 109 & 0.74 \\
\hline & CUA & 215 & 0.82 & & $\mathrm{CCA}$ & 185 & 1.26 \\
\hline & CUG & 92 & 0.35 & & CCG & 88 & 0.6 \\
\hline \multirow[t]{2}{*}{ His } & CAU & 245 & 1.54 & Arg & CGU & 188 & 1.39 \\
\hline & CAC & 73 & 0.46 & & CGC & 80 & 0.59 \\
\hline \multirow[t]{2}{*}{ Gln } & CAA & 425 & 1.51 & & CGA & 202 & 1.49 \\
\hline & CAG & 138 & 0.49 & & CGG & 62 & 0.46 \\
\hline \multirow[t]{3}{*}{ Ile } & AUU & 593 & 1.59 & Thr & $A C U$ & 358 & 1.85 \\
\hline & AUC & 189 & 0.51 & & $\mathrm{ACC}$ & 121 & 0.62 \\
\hline & $A \cup A$ & 339 & 0.91 & & $\mathrm{ACA}$ & 208 & 1.07 \\
\hline Met & AUG & 310 & 1 & & ACG & 88 & 0.45 \\
\hline \multirow[t]{2}{*}{ Asn } & AAU & 543 & 1.53 & Ser & AGU & 240 & 1.43 \\
\hline & AAC & 167 & 0.47 & & AGC & 57 & 0.34 \\
\hline \multirow[t]{2}{*}{ Lys } & AAA & 697 & 1.58 & Arg & AGA & 207 & 1.53 \\
\hline & AAG & 188 & 0.42 & & AGG & 74 & 0.55 \\
\hline \multirow[t]{4}{*}{ Val } & GUU & 282 & 1.46 & Ala & $\mathrm{GCU}$ & 348 & 1.61 \\
\hline & GUC & 137 & 0.71 & & GCC & $|5|$ & 0.7 \\
\hline & GUA & 235 & 1.22 & & $\mathrm{GCA}$ & 253 & 1.17 \\
\hline & GUG & 119 & 0.62 & & GCG & 114 & 0.53 \\
\hline \multirow[t]{2}{*}{ Asp } & GAU & 399 & 1.53 & Gly & GGU & 338 & 1.4 \\
\hline & GAC & 123 & 0.47 & & GGC & 126 & 0.52 \\
\hline \multirow[t]{2}{*}{ Glu } & GAA & 548 & 1.48 & & GGA & 345 & 1.42 \\
\hline & GAG & 194 & 0.52 & & GGG & 160 & 0.66 \\
\hline
\end{tabular}

Calculations were made from all coding regions combined. Due to difference in genome content, the total number of codons was different for all taxa.

DNA isolation in Ipomoea. One gram of tissue from a collection of very green seedlings originating from a selfed parental plant was used for Cuscuta exaltata, and one gram of stem tip tissue was used for Cuscuta obtusiflora. Partial fosmid libraries were constructed from the extracted DNA using the CopyControl Fosmid Library Production Kit (Epicentre, Madison, WI). Libraries were screened for clones containing plastid DNA according to McNeal et al[60]. A subset of clones covering the entire plastid genome was selected for each species, and clones were shotgun sequenced and the reads assembled according to previously described methods [61]. Genome annotations were completed using DOGMA [62] in combination with manual sequence alignments of previously annotated genes from available related species. Sequences were deposited in Genbank with accession numbers EU118126
(Ipomoea), EU189132 (C. exaltata), and EU189133 (C. obtusiflora).

\section{Molecular Evolutionary Analyses}

Phylogenies for each gene were constructed in PAUP*4.0b10 [63] under various Maximum Parsimony, Neighbor-Joining, and Maximum Likelihood criteria, including the following related taxa with full plastid genome sequences publicly available: Nicotiana tabacum (Genbank accession NC 001879) and Atropa belladona (NC 004561)(Solanaceae, Solanales, Asteridae), Panax ginseng (NC 006290)(Araliaceae, Apiales, Asteridae), and Spinacia oleracea (NC 002202)(Caryophyllidae) as an outgroup. All sequenced genes appeared orthologous, with only minor, method-dependent aberrations from the expected phylogeny which were probably due to extreme 
rate heterogeneity between taxa [64]. Maximum Likelihood analyses that were performed under the General Time-Reversible model with gamma distribution of among-site variation (GTR+gamma) and model parameters estimated from the data were most accurate at obtaining the expected phylogeny from the data and were used for subsequent phylogenetic reconstruction of combinedgene datasets.

Pairwise estimates of synonymous substitutions per synonymous site $\left(d_{S}\right)$ and nonsynonymous nucleotide substitutions per nonsynonymous site $\left(d_{N}\right)$ and standard errors were computed under the Kumar method using MEGA 2.1 [65] for each gene and for classes of genes that together encode subunits of larger proteins. ATP synthase genes, 6 genes, 4344 aligned characters (atp); cytochrome b6/f complex subunits, 6 genes, 2622 aligned characters (pet); photosystem I and II protein subunits, 19 genes, 11730 aligned characters ( $p s a$ and $p s b=p s$ ); large and small ribosomal protein subunits, 17 genes, 7686 aligned characters ( $r p l$ and $r p s=r p)$; plastid-encoded RNA polymerase 4 genes, 11958 aligned characters (rpo); and NADH-dehydrogenase, 11 genes, 10,653 aligned characters $(n d h)$ were predefined classes of genes examined. Pairwise $d_{S^{\prime}} d_{N^{\prime}}$ and amino acid p-distance were also calculated between Epifagus virginiana and Panax, the closest available outgroup to both it and Cuscuta.

Maximum Likelihood estimates of synonymous substitution rates and the ratio of nonysnonymous to synonymous rates $(\mathrm{R})$ for each branch of the combined-gene dataset phylogenies were calculated under the MG94 $\times$ HKY $3 \times 4$ codon model in the HYPHY .99beta package [66]. HYPHY was also used to conduct likelihood ratio tests (LRTs) between trees with universally constrained synonymous rates and $\mathrm{R}$ versus trees with each respective parameter free from constraint on one branch. Branches leading to Convolvulaceae (Ipomoea + both Cuscuta species), Cuscuta, and each individual Cuscuta species were tested for significant p-values in this manner. Additionally, pairwise relative rates tests were conducted for each gene class using various combinations of taxa with all parameters constrained as the null hypothesis and all parameters unconstrained as the alternate hypothesis. Pairwise relative ratio tests were conducted in HYPHY between the combined datasets with either synonymous or nonsynonymous distances constrained as the null hypothesis to determine whether there was significant heterogeneity in either across gene classes. Parameters were estimated independently for each branch. Finally, GCUA [67] was used to determine relative synonymous codon usage across all coding sequences for each genome to identify any changes in codon bias that may have accompanied tRNA loss or relaxed selection for photosynthesis.

\section{Note in Proof}

Two additional Cuscuta plastid genome sequences were published (Funk et al. BMC Plant Biology 2007, 7:45) during the late stages of review of our manuscript. Although the analyses of the data in our manuscripts demonstrate little overlap, the plastid genome structure and content of Cuscuta reflexa in that manuscript closely parallels our data from Cuscuta exaltata. Likewise, the sequence of Cuscuta gronovii demonstrates similar structure and gene content as Cuscuta obtusiflora.

\section{Competing interests}

The author(s) declares that there are no competing interests.

\section{Authors' contributions}

JRM cultivated the plants, produced and screened the partial genomic fosmid libraries, annotated and analyzed the plastid genomes, and drafted the manuscript. JVK subcloned, sequenced, and assembled reads for the selected fosmid clones. JLB and CWD helped conceive, design, and coordinate the study and made large contributions to manuscript editing. All authors read and approved the final manuscript.

\section{Acknowledgements}

We would like to thank Mauricio Bonifacino and Daniel Austin for assistance in obtaining plant material for the study, Tony Omeis for greenhouse assistance, Tim Chumley for technical support, Robert Jansen for general support and encouragement, and David Geiser, Stephen Schaeffer, Andrew Stephenson, and Kai Müeller for critical review of the manuscript. We also thank the Pennsylvania State University Department of Biology for support, including a Henry W. Popp fellowship awarded to JRM. This research was supported by National Science Foundation Grants DEB-0206659 and DEB0120709 and partly performed under the auspices of the US Department of Energy's Office of Science, Biological and Environmental Research Program, and by the University of California, Lawrence Berkeley National Laboratory under Contract No. DE-AC02-05CHI I 23 I.

\section{References}

I. Barkman TJ, McNeal JR, S. L, Coat G, Croom HB, Young ND, dePamphilis CW: Mitochondrial DNA suggests 12 origins of parasitism in angiosperms and implicates parasitic plants as vectors of horizontal gene transfer. to be submitted to Proceedings of the National Academy of Sciences of the United States of America .

2. Bidartondo MI, Bruns TD: Extreme specificity in epiparasitic Monotropoideae (Ericaceae): widespread phylogenetic and geographical structure. Molecular Ecology 200I, 1 0:2285-2295.

3. Bidartondo MI, Redecker D, Hijri I, Wiemken A, Bruns TD, Dominguez L, Sersic A, Leake JR, Read DJ: Epiparasitic plants specialized on arbuscular mycorrhizal fungi. Nature 2002, 419:389-392.

4. Martin W, Herrmann RG: Gene transfer from organelles to the nucleus: How much, what happens, and why? Plant Physiology 1998, II 8:9-17.

5. Nickrent DL, Starr EM: High rates of nucleotide substitution in nuclear small-subunit (18S) rDNA from holoparasitic flowering plants. Journal of Molecular Evolution 1994, 39:62-70.

6. Wolfe $\mathrm{KH}$, Li WH, Sharp PM: Rates of nucleotide substitution vary greatly among plant mitochondrial, chloroplast, and nuclear DNAs. Proceedings of the National Academy of Sciences of the United States of America 1987, 84:9054-9058. 
7. Kuijt J: Biology of Parasitic Flowering Plants. Berkeley and Los Angeles, University of California Press; 1969.

8. Wolfe KH, Morden CW, Palmer JD: Function and evolution of a minimal plastid genome from a nonphotosynthetic parasitic plant. Proceedings of the National Academy of Sciences of the United States of America 1992, 89: 10648-10652.

9. dePamphilis CW, Palmer JD: Loss of photosynthetic and chlororespiratory genes from the plastid genome of a parasitic flowering plant. Nature 1990, 348:337-339.

10. Ems SC, Morden CW, Dixon CK, Wolfe KH, dePamphilis CW, Palmer JD: Transcription, splicing and editing of plastid RNAs in the nonphotosynthetic plant Epifagus virginiana. Plant Molecular Biology 1995, 29:72 I-733.

II. Delavault P, Sakanyan V, Thalouarn P: Divergent evolution of two plastid genes, rbcL and atpB, in a non-photosynthetic parasitic plant. Plant Molecular Biology 1995, 29:107I-1079.

12. Delavault PM, Russo NM, Lusson NA, Thalouarn PA: Organization of the reduced plastid genome of Lathraea clandestina, an achlorophyllous parasitic plant. Physiologia Plantarum 1996, 96:674-682.

13. Lohan $\mathrm{A}$, Wolfe $\mathrm{KH}$ : A subset of conserved tRNA genes in plastid DNA of nongreen plants. Genetics 1998, 150:425-433.

14. Wimpee CF, Morgan R, Wrobel RL: Loss of transfer-RNA genes from the plastid 16S-23S ribosomal-RNA gene spacer in a parasitic plant. Current Genetics 1992, $21: 417-422$.

15. Nickrent DL, Yan OY, Duff RJ, dePamphilis CW: Do nonasterid holoparasitic flowering plants have plastid genomes? Plant Molecular Biology 1997, 34:717-729.

16. Nickrent DL, Duff RJ, Konings DAM: Structural analyses of plastid-derived 16S rRNAs in holoparasitic angiosperms. Plant Molecular Biology 1997, 34:731-743.

17. van der Kooij TAW, Krause K, Dorr I, Krupinska K: Molecular, functional and ultrastructural characterisation of plastids from six species of the parasitic flowering plant genus Cuscuta. Planta 2000, 21 0:701-707.

18. Yunker TG: The Genus Cuscuta. Memoirs of the Torrey Botanical Club 1932, I 8: I|3-331.

19. Machado MA, Zetsche K: A structural, functional and molecular analysis of plastids of the holoparasites Cuscuta reflexa and Cuscuta europaea. Planta 1990, 181:91-96.

20. Haberhausen $G$, Zetsche $K$ : Functional loss of ndh genes in an otherwise relatively unaltered plastid genome of the holoparasitic flowering plant Cuscuta reflexa. Plant Molecular Biology 1994, 24:217-222.

21. Haberhausen G, Valentin K, Zetsche K: Organization and sequence of photosynthetic genes from the plastid genome of the holoparasitic flowering plant Cuscuta reflexa. Molecular \& General Genetics 1992, 232:154-16I.

22. Hibberd JM, Bungard RA, Press MC, Jeschke WD, Scholes JD, Quick WP: Localization of photosynthetic metabolism in the parasitic angiosperm Cuscuta reflexa. Planta 1998, 205:506-513.

23. Bungard RA, Ruban AV, Hibberd JM, Press MC, Horton P, Scholes JD: Unusual carotenoid composition and a new type of xanthophyll cycle in plants. Proceedings of the National Academy of Sciences of the United States of America 1999, 96: I I35-II 39.

24. Revill MJW, Stanley S, Hibberd JM: Plastid genome structure and loss of photosynthetic ability in the parasitic genus Cuscuta. Journal of Experimental Botany 2005, 56:2477-2486.

25. Sherman TD, Pettigrew WT, Vaughn KC: Structural and immunological characterization of the Cuscuta pentagona L. chloroplast. Plant and Cell Physiology 1999, 40:592-603.

26. Krause K, Berg S, Krupinska K: Plastid transcription in the holoparasitic plant genus Cuscuta: parallel loss of the rrn 16 PEP-promoter and of the rpoA and rpoB genes coding for the plastid-encoded RNA polymerase. Planta 2003, 216:815-823.

27. Stefanovic S, Krueger L, Olmstead RG: Monophyly of the Convolvulaceae and circumscription of their major lineages based on DNA sequences of multiple chloroplast loci. American Journal of Botany 2002, 89:1510-1522.

28. Stefanovic S, Olmstead RG: Down the slippery slope: plastid genome evolution in Convolvulaceae. Journal of Molecular Evolution 2005, 61:292-305

29. Stefanovic S, Austin DF, Olmstead RG: Classification of Convolvulaceae: A phylogenetic approach. Systematic Botany 2003, 28:79|-806.
30. Stefanovic $S$, Olmstead RG: Testing the phylogenetic position of a parasitic plant (Cuscuta, Convolvulaceae, Asteridae): Bayesian inference and the parametric bootstrap on data drawn from three genomes. Systematic Biology 2004, 53:384-399.

31. Neyland R: A phylogeny inferred from large ribosomal subunit (26S) rDNA sequences suggests that Cuscuta is a derived member of Convolvulaceae. Brittonia 200I, 53:108-II5.

32. Palmer JD: Comparative organization of chloroplast genomes. Ann Rev Genet 1985, 19:325-354.

33. McNeal JR: Chapter 5: "Systematics and plastid genome evolution of the cryptically photosynthetic parasitic plant genus Cuscuta (Convolvulaceae)" in Systematics and plastid genome evolution in the parasitic plant genus Cuscuta (dodder). In Department of Biology University Park, The Pennsylvania State University; 2005.

34. Schmitz-Linneweber C, Regel R, Du TG, Hupfer H, Herrmann RG, Maier RM: The plastid chromosome of Atropa belladonna and its comparison with that of Nicotiana tabacum: The role of RNA editing in generating divergence in the process of plant speciation. Molecular Biology and Evolution 2002, 19:1602-1612.

35. Millen RS, Olmstead RG, Adams KL, Palmer JD, Lao NT, Heggie L, Kavanagh TA, Hibberd JM, Giray JC, Morden CW, Calie PJ, Jermiin LS, Wolfe KH: Many parallel losses of infA from chloroplast DNA during angiosperm evolution with multiple independent transfers to the nucleus. Plant Cell 200I, 13:645-658.

36. Kim KJ, Lee HL: Complete chloroplast genome sequences from Korean ginseng (Panax schinseng Nees) and comparative analysis of sequence evolution among 17 vascular plants. DNA Research 2004, I I:247-26I.

37. Schmitz-Linneweber C, Maier RM, Alcaraz JP, Cottet A, Herrmann RG, Mache R: The plastid chromosome of spinach (Spinacia oleracea): complete nucleotide sequence and gene organization. Plant Molecular Biology 200I, 45:307-3I5.

38. Downie SR, Palmer JD: Use of chloroplast DNA rearrangements in reconstructing plant phylogeny. In Molecular Systematics of Plants Edited by: Soltis DE, Soltis PS and Doyle JJ. London, UK, Chapman and Hall; 1992:14-35.

39. Wakasugi T, Tsudzuki J, Ito S, Nakashima K, Tsudzuki T, Sugiura M: Loss of all ndh genes as determined by sequencing the entire chloroplast genome of the Black Pine Pinus thunbergii. Proceedings of the National Academy of Sciences of the United States of America 1994, 91:9794-9798.

40. Bommer D, Haberhausen G, Zetsche K: A large deletion in the plastid DNA of the holoparasitic flowering plant Cuscuta reflexa concerning two ribosomal-proteins (rp/2, rp/23), one transfer-RNA (trnl) and an orf2280 homolog. Current Genetics 1993, 24:17I-176.

4I. McNeal JR: Chapter 3: "Disappearance of introns promotes adaptive change and loss of a highly conserved maturase" in Systematics and molecular evolution in the parasitic plant genus Cuscuta (dodder). In Department of Biology University Park, The Pennsylvania State University; 2004.

42. Berg S, Krause K, Krupinska K: The rbcL genes of two Cuscuta species, $\mathrm{C}$. gronovii and $\mathrm{C}$. subinclusa, are transcribed by the nuclear-encoded plastid RNA polymerase (NEP). Planta 2004, 21 9:54I-546.

43. Mogensen HL: The hows and whys of cytoplasmic inheritance in plants. American Journal of Botany 1996, 83:383-404.

44. Liere K, Maliga P: Plastid RNA polymerases in higher plants. In Regulation of photosynthesis Volume II. Edited by: Aro E and Andersson B. Dordrecht, Boston, London, Kluwer Academic Publishers; 2001:29-49.

45. Kuroda $\mathrm{H}$, Maliga $\mathrm{P}$ : The plastid clpP I protease gene is essential for plant development. Nature 2003, 425:86-89.

46. Morden CW, Wolfe KH, Depamphilis CW, Palmer JD: Plastid translation and transcription genes in a nonphotosynthetic plant - Intact, missing and pseudo genes. Embo Journal I991, 10:328I-3288.

47. Leebens-Mack JH, dePamphilis CW: Power analysis of tests for loss of selective constraint in cave crayfish and nonphotosynthetic plant lineages. Molecular Biology and Evolution 2002, 19:1292-1302.

48. Wolfe $A D$, dePamphilis $C W$ : The effect of relaxed functional constraints on the photosynthetic gene rbcL in photosynthetic and nonphotosynthetic parasitic plants. Molecular Biology and Evolution 1998, 15:1243-1258. 
49. Wolfe $A D$, dePamphilis CW: Alternate paths of evolution for the photosynthetic gene rbcL in four nonphotosynthetic species of Orobanche. Plant Molecular Biology 1997, 33:965-977.

50. Bremer B, Bremer K, Heidari N, Erixon P, Olmstead RG, Anderberg $A A$, Kallersjo $M$, Barkhordarian E: Phylogenetics of asterids based on 3 coding and 3 non-coding chloroplast DNA markers and the utility of non-coding DNA at higher taxonomic levels. Molecular Phylogenetics and Evolution 2002, 24:274-301.

5I. Wilson RJM, Denny PW, Preiser PR, Rangachari K, Roberts K, Roy A, Whyte A, Strath M, Moore DJ, Moore PW, Williamson DH: Complete plastid gene map of the plastid-like DNA of the malaria parasite Plasmodium falciparum. Journal of Molecular Biology 1996, 26 I: I55-I72

52. Gockel G, Hachtel W, Melkonian M: Complete gene map of the plastid genome of the nonphotosynthetic euglenoid flagellate Astasia longa. Protist 2002, I 5 I:347-35 I.

53. deKoning AP, Keeling PJ: The complete plastid genome sequence of the parasitic green alga Helicosporidium $\mathrm{sp}$. is highly reduced and structured. BMC Biology 2006, 4:.

54. Knauf $U$, Hachtel $W$ : The genes encoding subunits of ATP synthase are conserved in the reduced plastid genome of the heterotrophic alga Prototheca wickerhamii. Molecular Genetics and Genomics 2002, 267:492-497.

55. Barbrook AC, J. HC, Purton S: Why are plastid genomes retained in non-photosynthetic organisms? Trends in Plant Science 2006, I I:101-108.

56. Schwender J, Goffman F, Ohlrogge JB, Shachar-Hill Y: Rubisco without the Calvin cycle improves the carbon efficiency of developing green seeds. Nature 2004, 432:779-782.

57. Sherman TD, Pettigrew WT, Vaughn KC: Structural and immunological characterization of the Cuscuta pentagona L-chloroplast. Plant and Cell Physiology 1999, 40:592-603.

58. Waller RF, Keeling PJ, Donald RGK, Striepen B, Handman E, LangUnnasch N, Cowman A, Besra GS, Roos DS, McFadden GI: Nuclearencoded proteins target to the plastid in Toxoplasma gondii and Plasmodium falciparum. Cell Biology 1998, 95: I 2352-I 2357.

59. Borza T, Popescu CE, Lee RW: Multiple metabolic roles for the nonphotosynthetic plastid of the green alga Prototheca wickerhamii. Eukaryotic Cell 2005, 4:253-26I.

60. McNeal JR, Leebens-Mack JH, Arumuganathan K, Kuehl JV, Boore JL, dePamphilis CW: Using partial genomic fosmid libraries for sequencing complete organellar genomes. Biotechniques 2006, 41:69-73.

6I. Jansen RK, Raubeson LA, Boore JL, dePamphilis CW, Chumley TW, Haberle RC, Wyman SK, Alverson AJ, Peery R, Herman SJ, Fourcade HM, Kuehl JV, McNeal JR, Leebens-Mack J, Cui L: Methods for obtaining and analyzing whole chloroplast genome sequences. Methods in Enzymology 2005, 395:348-384.

62. Wyman SK, Jansen RK, Boore JL: Automatic annotation of organellar genomes with DOGMA. Bioinformatics 2004, 20:3252-3255

63. Swofford DL: PAUP*. Phylogenetic Analysis Using Parsimony (*and Other Methods). Version 4.0bl0 edition. Sunderland, MA, Sinauer Associates; 2002.

64. Felsenstein J: Cases in which parsimony and compatibility methods will be positively misleading. Systematic Zoology 1978, 27:40I-4I0.

65. Kumar S, Tamura K, Jakobsen I, Nei M: Molecular Evolutionary Genetics Analysis (MEGA) version 2.I. 2000.

66. Kosakovsky-Pond SL, Frost SDW, Muse SV: HyPhy: hypothesis testing using phylogenies. Bioinformatics 2004:bti079.

67. Mclnerney JO: GCUA (General Codon Usage Analysis). Bioinformatics 1998, 14:372-373.
Publish with Bio Med Central and every scientist can read your work free of charge

"BioMed Central will be the most significant development for disseminating the results of biomedical research in our lifetime. " Sir Paul Nurse, Cancer Research UK

Your research papers will be:

- available free of charge to the entire biomedical community

- peer reviewed and published immediately upon acceptance

- cited in PubMed and archived on PubMed Central

- yours - you keep the copyright
BioMedcentral

Page 22 of 22 